\title{
Observations and Modeling of GHG Concentrations and Fluxes Over India
}

\section{Coordinating Lead Authors}

Supriyo Chakraborty, Indian Institute of Tropical Meteorology (IITM-MoES), Pune, India, e-mail: supriyo@tropmet.res.in (corresponding author)

Yogesh K. Tiwari, Indian Institute of Tropical Meteorology (IITM-MoES), Pune, India

\section{Lead Authors}

Pramit Kumar Deb Burman, Indian Institute of Tropical Meteorology (IITM-MoES), Pune, India Somnath Baidya Roy, Centre for Atmospheric Sciences, Indian Institute of Technology Delhi, India Vinu Valsala, Indian Institute of Tropical Meteorology (IITM-MoES), Pune, India

\section{Contributing Authors}

Smrati Gupta, Indian Institute of Tropical Meteorology (IITM-MoES), Pune, India Abirlal Metya, Indian Institute of Tropical Meteorology (IITM-MoES), Pune, India Shilpa Gahlot, Centre for Atmospheric Sciences, Indian Institute of Technology Delhi, India

\section{Review Editors}

V. K. Dadhwal, Indian Institute of Space Science and Technology, Thiruvananthapuram, India Govindsamy Bala, Centre for Atmospheric and Oceanic Sciences, Indian Institute of Science, Bengaluru, India Shamil Maksyutov, National Institute for Environmental Studies, Tsukuba, Japan Prabir Patra, Japan Agency for Marine-Earth Science and Technology, Yokohama, Japan P. Mahesh, National Remote Sensing Center, Indian Space Research Organization, Hyderabad, India

\section{Corresponding Author}

Supriyo Chakraborty, Indian Institute of Tropical Meteorology (IITM-MoES), Pune, India, e-mail: supriyo@tropmet.res.in

The original version of this chapter was revised. On page 88 , the last sentence has been changed. The correction to this chapter is available at https://doi.org/10.1007/978-981-15-4327-2_13 


\section{Key Messages}

- The surface $\mathrm{CO}_{2}$ concentration observed at Sinhagad site, located in the western part of India, shows higher seasonal cycle amplitude as compared to the observations at Mauna Loa in the Pacific region (Fig. 4.1). The higher amplitude is caused by strong local-regional biospheric activity.

- The surface $\mathrm{CO}_{2}$ concentration amplitude in the western Indian region is increasing with time, likely driven by the enhanced biospheric activities as well as the changes in nearby oceanic fluxes. To ascertain the driving mechanism behind this as well as long-term variability at country scale, a strategically designed network of long-term surface $\mathrm{CO}_{2}$ concentration and associated flux observations is essential over India.

- Recent studies using flux tower measurements show that the carbon fluxes in Indian forests vary widely across the ecosystems. The Kaziranga forest in Northeast India sequesters maximum carbon during pre-monsoon season, whereas the forests in Haldwani and Barkot in northern India sequester maximum carbon during the summer monsoon season. The forests in Betul in central India, mangroves in Sundarbans in east India and forests in Kosi-Katarmal in north India sequester maximum carbon during post-monsoon, whereas mangroves in Pichavaram in the east coast of south India sequester maximum carbon during the winter season (Fig. 4.5).

- Satellite-derived vegetation indices indicate increasing vegetation productivity over India during recent decades.

- Modeling studies show that even though the Indian terrestrial ecosystem has not historically been a strong source or sink of carbon, it is behaving as a carbon sink since the 1980s. The terrestrial carbon sink is maintained primarily by the carbon fertilization effect aided to some extent by forest conservation, management, and reforestation policies in recent decades (Sect. 4.4.1).

- Surface GHGs measurement sites in India are sparse in nature. In the absence of long-term observational records and a comprehensive modeling of biogeochemical processes, there is a limited understanding of the dynamics of GHGs variability in India. Expansion of observational network as well as development of process-based biogeochemical and coupled climate-carbon models may fill this knowledge gap. Such expanded capabilities would help improve the assessments of the mitigation potential of Indian ecosystem in the future (Sect. 4.5).

\section{Box 4.1 Preamble}

In order to study the effect of primary drivers of climate change, observational data of at least a few decades ("climate timescale") are required. Such knowledge is also useful for a meaningful interpretation of a reliable estimate of future projection of the drivers. The primary drivers of climate change in the industrial era are the greenhouse gases (GHGs) which absorb the terrestrial radiation strongly. It is now well established that increase in the GHGs concentrations during the past century has been due to the anthropogenic activities, such as the fossil fuel consumption and land use land cover changes. The largest instrumental data of $\mathrm{CO}_{2}$ concentration, reported as dry-air mole fraction, are available since the international geophysical year (1957-1958) from South Pole and Mauna Loa, Hawaii. The latter is considered as a reference to global-mean $\mathrm{CO}_{2}$ concentration. In India however, the longest $\mathrm{CO}_{2}$ record is available only for a couple of decades. Thus, most studies are limited to
Fig. 4.1 Seasonal variation of $\mathrm{CO}_{2}$ mixing ratio at two tropical sites. The amplitude of $\mathrm{CO}_{2}$ mixing ratio variability at Sinhagad, India (blue line), is much higher than that observed at a comparable latitudinal range $\left(18.3-19.4^{\circ} \mathrm{N}\right)$, Mauna Loa in the Pacific region (red line). The data were obtained from Tiwari et al. (2014) re-plotted and extended till 2015

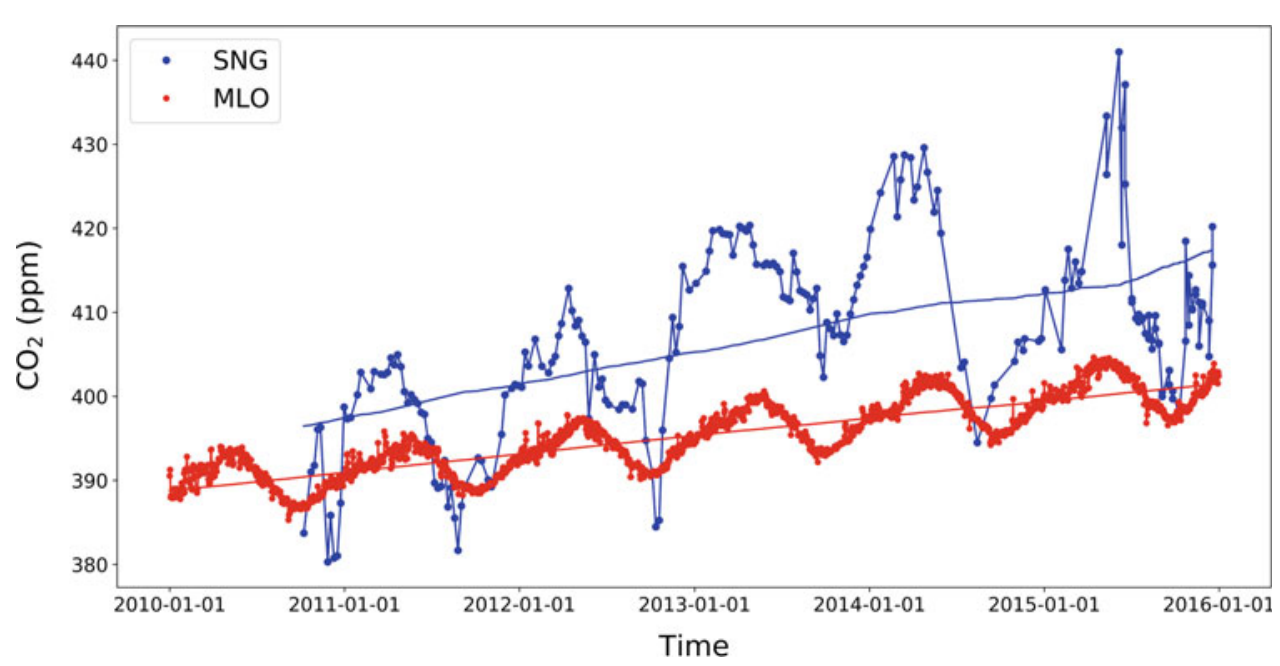


short-term changes that span over diurnal to inter-annual timescale. The lack of robust observational records is a severe constraint to make a reliable assessment of the trends in GHGs fluxes. In this chapter, we provide an overview of the measurement of a few GHGs concentration, how carbon is sequestered in natural ecosystems as determined by the eddy covariance technique and some model-based results for India. The chapter provides a summary assessment of GHGs (mainly $\mathrm{CO}_{2}, \mathrm{CH}_{4}$ and $\mathrm{N}_{2} \mathrm{O}$ )-related research in India. Other trace gases, such as ozone, $\mathrm{SO}_{2}$ and CFCs, have been discussed in Chap. 5. A brief discussion on the upper ocean carbon cycle in the Indian Ocean has been presented in Chap. 10.

\subsection{Introduction}

There is a general scientific consensus that radiative processes associated with increasing concentrations of greenhouse gases (GHGs) and related feedback processes are responsible for the global warming and climate change (IPCC 2013). The important GHGs in the earth's environment are carbon dioxide $\left(\mathrm{CO}_{2}\right)$, methane $\left(\mathrm{CH}_{4}\right)$, nitrous oxide $\left(\mathrm{N}_{2} \mathrm{O}\right)$, halocarbons and ozone in the lower atmosphere. The concentrations of $\mathrm{CO}_{2}, \mathrm{CH}_{4}$ and $\mathrm{N}_{2} \mathrm{O}$ have significantly increased since the beginning of the industrial era (Ciais et al. 2013). Among the GHGs of anthropogenic origin, the increase of atmospheric carbon is of primary concern because $\mathrm{CO}_{2}$ has a long lifetime in the atmosphere ( $\sim 100$ years $)$. The concentration of atmospheric $\mathrm{CO}_{2}$ was ca. $280 \mathrm{ppm}$ during the pre-industrial period. This has exceeded $400 \mathrm{ppm}$ in recent time (https://www.esrl.noaa.gov/gmd/ccgg/trends). The average growth rate has been estimated at $2.11 \mathrm{ppm}$ per year during the last decade, and a value of $410 \mathrm{ppm}$ was observed in 2018 (https://www.esrl.noaa.gov/gmd). However, the $\mathrm{CO}_{2}$ mixing ratio shows considerable variability on local to regional scale. For example, the amplitude of $\mathrm{CO}_{2}$ variations observed in the west peninsular India ( $\sim 25 \mathrm{ppm})$ was much higher than that observed in the Mauna Loa observatory in the Pacific region ( $\sim 6 \mathrm{ppm}$ ) (see Fig. 4.1), though both the sites are situated within a narrow latitude band (Sinhagad: $18.35^{\circ} \mathrm{N}$; Mauna Loa: $19.4^{\circ} \mathrm{N}$ ). The measurement in India is likely affected by regional terrestrial biospheric processes and marine sources (Tiwari et al. 2014).

The concentration of $\mathrm{CH}_{4}$ has increased from 700 to $1857 \mathrm{ppb}$ and that of $\mathrm{N}_{2} \mathrm{O}$ from 270 to $321 \mathrm{ppb}$ since pre-industrial era (IPCC 2007). Although the concentrations of $\mathrm{CH}_{4}$ and $\mathrm{N}_{2} \mathrm{O}$ are small compared to that of $\mathrm{CO}_{2}$, their global warming potential (GWP) in terms of radiative forcing is several times (28 and 265 for $\mathrm{CH}_{4}$ and $\mathrm{N}_{2} \mathrm{O}$, respectively, to 100-year time horizon) higher than that of an equivalent amount of $\mathrm{CO}_{2}$. Residence time of $\mathrm{CO}_{2}$ in the atmosphere is $\sim 100$ years, whereas that of $\mathrm{CH}_{4}$ and $\mathrm{N}_{2} \mathrm{O}$ is about 10 years and 120 years, respectively. The increase in $\mathrm{CH}_{4}$ concentration is mainly dominated by agricultural and animal husbandry operations, and that of $\mathrm{N}_{2} \mathrm{O}$ is due to agricultural practices (Liu et al. 2019).

\subsection{Observational Aspects of GHGs Research in India}

In India, there are very few research organizations involved in the observational aspects of GHGs research with a long-term perspective. One of the earliest attempts was made by a group at the National Institute of Oceanography (NIO) in Goa and Physical Research Laboratory (PRL) in Ahmedabad, which took a major initiative in measuring GHGs at a coastal site in western India, Cabo de Rama, also known as Cape Rama (acronym CRI: $15.08^{\circ} \mathrm{N}, 73.83^{\circ} \mathrm{E}$, $50 \mathrm{~m} \mathrm{ASL}$ ) in association with the Commonwealth Scientific and Industrial Research Organisation (CSIRO), Australia (Bhattacharya et al. 2009). The CRI site is located closer to the shoreline, free from any major vegetation and away from habitation (Tiwari et al. 2011). Routine measurement of the concentrations of $\mathrm{CO}_{2}, \mathrm{CH}_{4}, \mathrm{CO}, \mathrm{N}_{2} \mathrm{O}$ and $\mathrm{H}_{2}$ was carried out at the bimonthly time intervals. Additionally, carbon $\left(\delta^{13} \mathrm{C}\right)$ and oxygen $\left(\delta^{18} \mathrm{O}\right)$ isotopic ratios of $\mathrm{CO}_{2}$ were also measured. The observational record is available for about a decade (1992-2002) and also for a period of 2009-2013.

In the next phase of the carbon cycle study in India, the Indian Space Research Organisation (ISRO) started the National Carbon Project (NCP) under the auspices of the ISRO Geosphere-Biosphere Program (IGBP) in the early phase of the 2010s. The NCP endeavors to understand the GHGs dynamics and estimate their budget by means of a robust observational network across the country (Chanda et al. 2013, 2014; Sharma et al. 2013, 2014; Patel et al. 2011; Mahesh et al. 2014, 2016, 2019; Sreenivas et al. 2016, 2019; Jha et al. 2013, 2014; Rodda et al. 2016). At about the same time, another GHGs observational program $\left(\mathrm{CO}_{2}\right.$ and $\left.\mathrm{CH}_{4}\right)$ at a semi-urban hilly site near Pune, called Sinhagad (SNG), was initiated by the Indian Institute of Tropical Meteorology, Pune, under the patronage of the Ministry of Earth Sciences (MoES), Government of India. The SNG site is $200 \mathrm{~km}$ east of the Arabian Sea $\left(73.75^{\circ} \mathrm{E}, 18.35^{\circ} \mathrm{N}\right.$, $1600 \mathrm{~m}$ ASL) situated over the Western Ghats mountainous terrain of southwestern peninsular region of the Indian subcontinent. The location is relatively free from major vegetation and local habitation disturbances for GHGs measurement on a long-term perspective. Routine air sampling at SNG, from a $10 \mathrm{~m}$ meteorological tower at weekly intervals, has been operational since November 2009 (Tiwari 
et al. 2014). The main objectives were (a) to investigate the GHGs transport mechanisms pertaining to the Indian subcontinent, (b) to understand the causes behind the seasonality of atmospheric $\mathrm{CO}_{2}$ concentrations and (c) to develop a modeling framework (forward and inverse) for estimations of carbon sources and sinks over the Indian domain.

Among other studies, significant effort was made by the CSIR Fourth Paradigm Institute, Bengaluru (formerly CSIR Centre for Mathematical Modeling and Computer Simulation), in collaboration with a few other national and international research organizations, such as Laboratoire des sciences du climat et de l'environnement (LSCE) in Paris, France; National Institute of Ocean Technology in Chennai and Port Blair; and Indian Institute of Astrophysics, Bengaluru. Scientists from these institutes reported GHGs monitoring results at three sites Hanle $\left(32.78^{\circ} \mathrm{N}, 78.96^{\circ} \mathrm{E}\right.$, $4500 \mathrm{~m} \mathrm{ASL})$, Pondicherry $\left(11.91^{\circ} \mathrm{N}, 79.81^{\circ} \mathrm{E}, 6 \mathrm{~m} \mathrm{ASL}\right)$ and Port Blair $\left(11.62^{\circ} \mathrm{N}, 92.72^{\circ} \mathrm{E}, 17 \mathrm{~m} \mathrm{ASL}\right)$ during the period 2007-2011 (Lin et al. 2015). Hanle is a high-altitude site and is considered as northern hemispheric midlatitude representative location. Pondicherry and Port Blair are coastal and oceanic sites, respectively, located at similar latitudes. Measurements were based on weekly flask sampling, and the flask samples were analyzed at the LSCE, France, under the Indo-French collaborative project. The observed concentration of $\mathrm{CH}_{4}$ at Hanle peaked during the summer monsoon months, in contrast to the seasonal cycle at other sites including Pondicherry and Port Blair. High $\mathrm{CH}_{4}$ concentration during monsoon could be due to enhanced biogenic emissions from wetlands and rice fields.

Sreenivas et al. (2016) presented $\mathrm{CO}_{2}$ and $\mathrm{CH}_{4}$ measurements over Shadnagar $\left(17.03^{\circ} \mathrm{N}, 78^{\circ} 18 \mathrm{E}\right)$ at Telangana India. But unlike the Hanle observations, these authors found minimum $\mathrm{CH}_{4}$ during Indian summer monsoon and maximum during post-monsoon, indicating spatial heterogeneity in methane emissions and hence concentrations across the country. Maximum $\mathrm{CO}_{2}$ occurred during pre-monsoon in conformity with the other observations, such as SNG (Tiwari et al. 2014; Metya et al. 2020). The Physical Research Laboratory in Ahmedabad has also made significant contributions in this regard, especially in analyzing the GHGs dynamics in an urban environment of India. For example, Chandra et al. (2019) observed low concentration of $\mathrm{CO}_{2}$ at Ahmedabad during the monsoon season in conformity with the result obtained by Tiwari et al. (2014) for the Sinhagad station.

\subsubsection{Carbon Dioxide $\left(\mathrm{CO}_{2}\right)$}

Tiwari et al. (2014) presented a detailed account of the SNG record. According to these authors, the regional source contributions at SNG and also at CRI arise from the horizontal flow within the planetary boundary layer. Greater

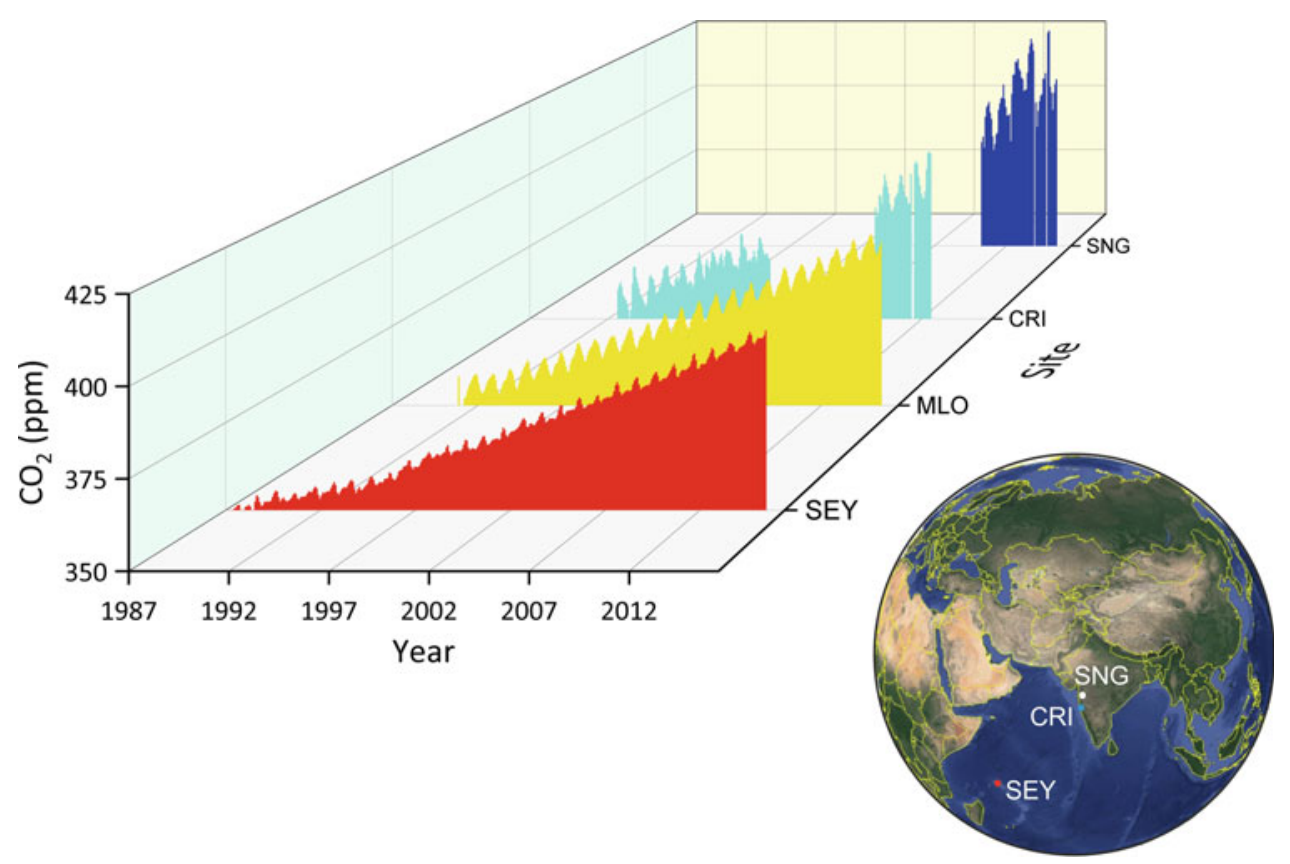

Fig. 4.2 Long-term records of $\mathrm{CO}_{2}$ (ppm) concentration variability observed in the western peninsular region of India and selected global background locations. The Indian observing sites Sinhagad (SNG) and Cape Rama (CRI) $\mathrm{CO}_{2}$ records are shown in blue and cyan bars, respectively. The $\mathrm{CO}_{2}$ record of an Indian Ocean island site Seychelles
(SEY) is shown in red, and the Mauna Loa (MLO) $\mathrm{CO}_{2}$ record is shown in yellow. These are to compare the Indian $\mathrm{CO}_{2}$ record with that of the global "background" record. The three sites (SNG, CRI, SEY) are also shown separately on the globe (globe credit: Google Earth) 
$\mathrm{CO}_{2}$ variability, $>5 \mathrm{ppm}$, is observed during winter, while it is reduced nearly by half during the summer (Tiwari et al. 2014). Unlike the long-term Mauna Loa observational records, the Indian GHGs record, as mentioned earlier, is short. Bose et al. (2014) developed a fractionation model and used it to reconstruct the $\mathrm{CO}_{2}$ variability using carbon isotopic analysis of tree rings from a western Himalayan region. These authors demonstrated that the tree ring-derived $\mathrm{CO}_{2}$ record for the last one hundred year had a good match with the ice core records of $\mathrm{CO}_{2}$ variability. Considering these observational records, we attempt to make a composite diagram of the $\mathrm{CRI}$ and the $\mathrm{SNG} \mathrm{CO}_{2}$ records to examine the regional features of the $\mathrm{CO}_{2}$ variability in the Indian context. Figure 4.2 shows the $\mathrm{CO}_{2}$ concentration variability approximately for the timescale of 1992-2013 with an intermittent gap from October 2002 to July 2009.

The CRI record is shown in cyan, while the blue bars represent the variability for the SNG site. The CRI and the SNG data show close resemblance, though a small difference is apparent. The $\mathrm{CO}_{2}$ amplitude in the case of the SNG site is slightly higher than the CRI site. In case of CRI, the sampling was done once in two months, whereas in case of SNG, the sampling was done on weekly time interval. Since samples collected at lower temporal resolution impart a smoothing effect, the variability is expected to be subdued in the case of the CRI site compared to the SNG site which had a sampling frequency of about eight times higher than the CRI site. Nevertheless, we may assume the combined dataset as a representative of the $\mathrm{CO}_{2}$ for this region and since there is no other known similar observational dataset available from the Indian region, we may call it as the "Indian $\mathrm{CO}_{2}$ record."

When this record is compared with the Mauna Loa $\mathrm{CO}_{2}$ (MLO) variability (see Fig. 4.2), one distinct feature is apparent. The Indian record shows higher amplitude, which has also been discussed earlier and illustrated in Fig. 4.1. In the earliest record, during the 1990s and 2000s, the CRI CO data also show slightly larger amplitude than the MLO record. But, in the second phase of measurement during the early 2010s, this amplitude in the case of the Indian record shows an increasing trend. The amplitudes are larger than that observed during the 1990s and 2000s, and much larger than the Mauna Loa record. As mentioned earlier, Bhattacharya et al. (2009) also measured $\delta^{13} \mathrm{C}$ of $\mathrm{CO}_{2}$ during 1993-2002 and observed a strong inverse correlation between $\mathrm{CO}_{2}$ and $\delta^{13} \mathrm{C}$. This anti-correlation suggests a land biospheric control rather than the oceanic modulation on the seasonal behavior of $\mathrm{CO}_{2}$ in this region. But according to a recent study, high-frequency $(1 \mathrm{~Hz})$ measurements of $\mathrm{CO}_{2}$ and $\mathrm{CH}_{4}$ concentrations using a laser-based $\mathrm{GHG}$ analyzer at SNG reveal that the oceanic emission of $\mathrm{CO}_{2}$ and/or background $\mathrm{CO}_{2}$ transported from the distant marine environment may also be playing a moderate role in determining the seasonal pattern of $\mathrm{CO}_{2}$ in this region (Metya et al. 2020). Though the marine influence needs to be further investigated to ascertain its role, the increasing amplitude may be attributed to enhanced land biospheric activities. It is important to mention that Barlow et al. (2015) observed similar behavior at a high latitude region, namely Barrow $\left(71.3^{\circ} \mathrm{N}, 156.6^{\circ} \mathrm{W}\right)$ in Alaska. They argue that the observed change in amplitude is partially due to an increase in "peak respiration" (contributes to increase the maxima in $\mathrm{CO}_{2}$ value) and a larger increase in "peak uptake" (contributes to extend the minima in $\mathrm{CO}_{2}$ value). Since respiration and photosynthetic uptake are by and large driven by vegetation, an increased vegetation cover seems to be the most likely reason for increased $\mathrm{CO}_{2}$ amplitude. One of the reasons could be that the vegetation and/or the forest cover are probably increasing, at least in the western part of India. In the last twenty years, the surface characteristics may have changed significantly, and interestingly, the forest cover has increased in India (MoEFCC 2015, 2018). On the contrary, some studies show that the Indian forest cover has been decreasing, at least for the last couple of decades (Meiyappan et al. 2017). Needless to say that an accurate estimate of Indian forest cover and its characteristic behavior for different climatic zones/geographical locations in terms of its carbon sequestration potential are essential in order to better understand the carbon dynamics. For example, the Northeast Indian region is characterized by high forest cover (ca. 64\%; Jain et al. 2013) but its carbon dynamical characteristics are quite different from the rest of the country. Firstly, it shows a very different characteristic in terms of the timing of the maximum $\mathrm{CO}_{2}$ uptake on a seasonal scale compared to the rest of India (discussed later), and secondly it shows a large $\mathrm{CO}_{2}$ variability. Deb Burman et al. (2017) reported large amplitude of the $\mathrm{CO}_{2}$ concentration in a deciduous forest at Kaziranga in Assam (380-460 ppm) during the year of 2016. Though one year of data may not be generalized as representative values, it may be indicative of distinct spatial characteristics of $\mathrm{CO}_{2}$ seasonal pattern of different ecosystems in India. Analysis of such records provides useful information on the amplitude and phase of the time series by means of spectral decomposition technique (Barlow et al. 2015). Additionally, tree-ring based measurement of radiocarbon activity of the atmospheric air on sub-seasonal timescale would provide information about the fossil fuel component (Chakraborty et al. 2008) of the $\mathrm{CO}_{2}$ emission and may help to partition the $\mathrm{CO}_{2}$ emitted by the agricultural practices (Berhanu et al. 2017).

\subsubsection{Methane $\left(\mathrm{CH}_{4}\right)$}

Methane is the second most important anthropogenic GHG after atmospheric $\mathrm{CO}_{2}$ (on the scale of radiative forcing, 
which is about $+0.48 \mathrm{Wm}^{-2}$; Stocker et al. 2013). The pre-industrial $\mathrm{CH}_{4}$ concentration has been estimated as $700 \mathrm{ppb}$, but increased anthropogenic activities, such as the agricultural practices and industrial activities, have resulted in a steady increase of atmospheric $\mathrm{CH}_{4}$, up to $1803 \mathrm{ppb}$ in 2011 (Dlugokencky et al. 2011; Etheridge et al. 1998). It also plays an active role in tropospheric chemistry. $\mathrm{CH}_{4}$ is mainly lost by reaction with the $\mathrm{OH}$ radical, and hence it directly contributes to stratospheric water vapor increase (Keppler et al. 2006). $\mathrm{CH}_{4}$ emissions from the anthropogenic sources in India have grown from 18.85 to $20.56 \mathrm{Tg} \mathrm{yr}^{-1}$ during 1985-2008 (Garg et al. 2011). Patra et al. (2013) made a comprehensive analysis to estimate $\mathrm{CH}_{4}$ emission from the entire South Asian region which turned out to be

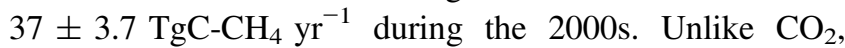
$\mathrm{CH}_{4}$ has a relatively short lifetime of $9-10$ years. Shorter lifetime, compared to $\mathrm{CO}_{2}, \mathrm{~N}_{2} \mathrm{O}$ or CFCs, is potentially useful for its sources and sinks to achieve a steady state or even a decline, thus reducing its impact on global climate change. A quasi-steady state was observed in the late 1990s and the first half of the 2000s (Dlugokencky et al. 2011). But increased emission of $\mathrm{CH}_{4}$, driven by the anthropogenic activities, later perturbed the equilibrium state (Rigby et al. 2008; Patra et al. 2016). The source and sink mechanism of $\mathrm{CH}_{4}$ is complex, and several components of its budget remain poorly constrained. Surface observation of $\mathrm{CH}_{4}$ in India is limited to a very few places, and those too provide only sporadic data; long time measurement is mostly absent. The CRI data provide one of the first long-term measurements of $\mathrm{CH}_{4}$ in India. Figure 4.3 shows the time series of the methane concentration at CRI (1993-2002; in cyan) in comparison with the MLO (in yellow) and the Seychelles site (SEY, an island in the equatorial Indian Ocean; in red). The data were obtained from the published results of Bhattacharya et al. (2009). It is noted that the seasonality in $\mathrm{CH}_{4}$ is much stronger at CRI than at MLO and SEY as shown in the inset. Another feature is that the $\mathrm{CH}_{4}$ mixing ratios at MLO were higher compared to the CRI values during the SW monsoon season (July-August; Fig. 4.3-inset). This provides a strong evidence of seasonality in $\mathrm{CH}_{4}$ fluxes in the Indian Ocean sector than in the Pacific (Bhattacharya et al. 2009; Patra et al. 2009). Analysis of the high-frequency data at the Sinhagad site also revealed a strong correlation between the $\mathrm{CO}_{2}$ and $\mathrm{CH}_{4}$ mixing ratios during the monsoon season but weak correlation in other seasons (Metya et al. 2020), indicating that the concentrations of both these gases during the monsoon season are also controlled by the monsoon circulation that originates in the Indian Ocean.

Methane shows distinct diurnal- and seasonal-scale variations (Sreenivas et al. 2016), which, unlike $\mathrm{CO}_{2}$, is characterized by a large variation on spatial domain. The seasonality of $\mathrm{CH}_{4}$ is found to be varying differently over different parts of India due to the complex interaction between the surface emissions and monsoonal transport patterns (Patra et al. 2009). For example, the eastern Himalayan station Darjeeling $\left(27.03^{\circ} \mathrm{N}, 88.26^{\circ} \mathrm{E}, 2000 \mathrm{~m}\right.$ ASL) captures episodes of increased $\mathrm{CH}_{4}$ concentrations throughout the year (Ganesan et al. 2013), but a northwestern Himalayan station Hanle experiences high values during summer monsoon season (Lin et al. 2015).

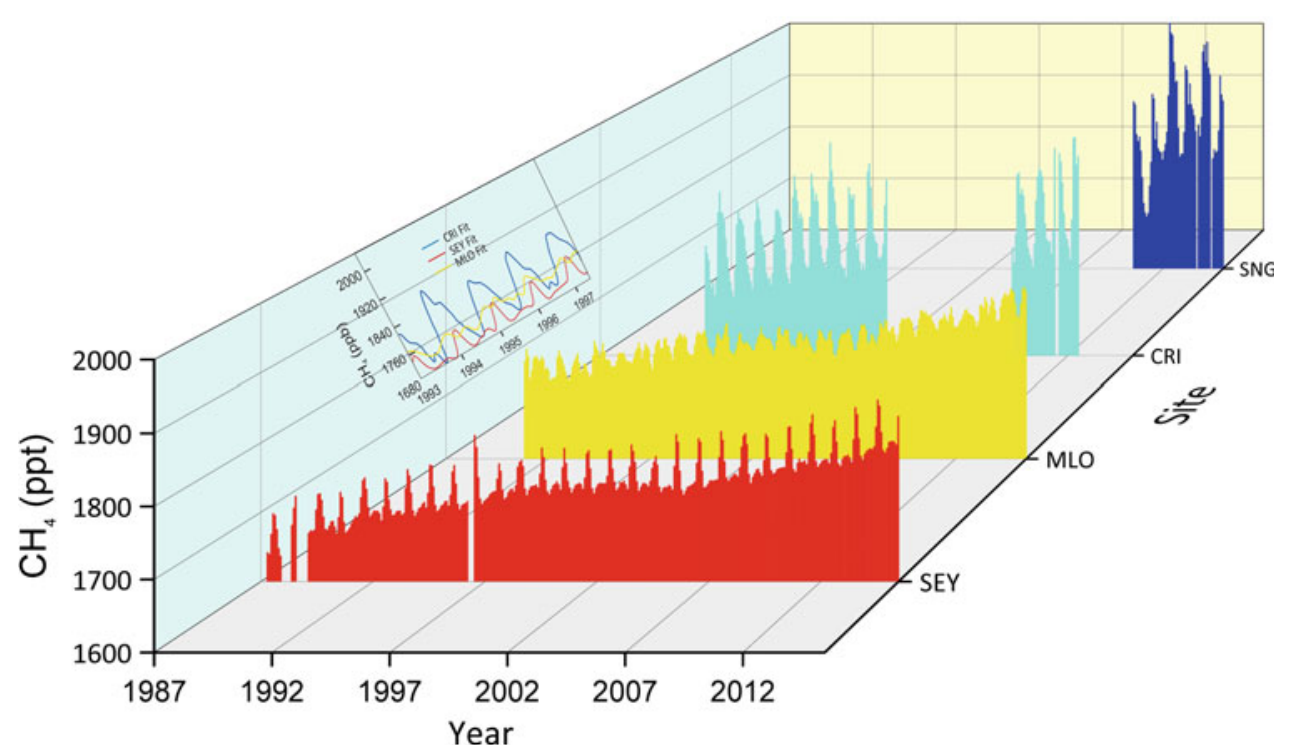

Fig. 4.3 $\mathrm{CH}_{4}$ mixing ratio in air samples observed at $\mathrm{SNG}$ (deep blue) and CRI (since 1993, cyan). The Mauna Loa (yellow) and the SEY data (red) have also been shown for comparison. The inset shows a zoomed version of the CRI data emphasizing the seasonal cycles. The data are available in Bhattacharya et al. (2009) and redrawn with modification 
Darjeeling experiences highest $\mathrm{CH}_{4}$ values during October-November, while Pondicherry at the southeastern coastal site and Port Blair in Andaman Islands register comparatively lower values (Lin et al. 2015). A dense observational network is required for understanding the spatial and temporal variations of $\mathrm{CH}_{4}$ over India, in particular the central Indian region which is characterized by sparse and intermittent observational network. Chandra et al. (2017) studied the variability of column dry-air mole fractions of methane $\left(\mathrm{XCH}_{4}\right)$ over India using GOSAT satellite retrievals. The satellite observation of the $\mathrm{XCH}_{4}$ is an integrated measure of $\mathrm{CH}_{4}$ densities at all altitudes from the surface to the top of the atmosphere. The Indian region was divided into eight subregions, and relationship between
$\mathrm{XCH}_{4}$ variability from surface to the upper troposphere with the surface emissions was discussed. More often, the $\mathrm{XCH}_{4}$ variabilities are strongly linked with the transport of air mass from outside the domain of interests and monsoon anticyclone in the middle-upper troposphere. Variations of $\mathrm{XCH}_{4}$ are controlled by both surface emissions and atmospheric transport largely driven by the monsoonal dynamics. Various observational techniques have been used to make estimates of top-down $\mathrm{CH}_{4}$ emissions in India (Schuck et al. 2010; Ganesan et al. 2013; Parker et al. 2015). It was shown that there is a little growth in the $\mathrm{CH}_{4}$ emissions in India during the period 2010-2015. The reported emissions in Ganesan et al. (2017) are 30\% lower than the bottom-up global inventory Emission Database for Global Atmospheric
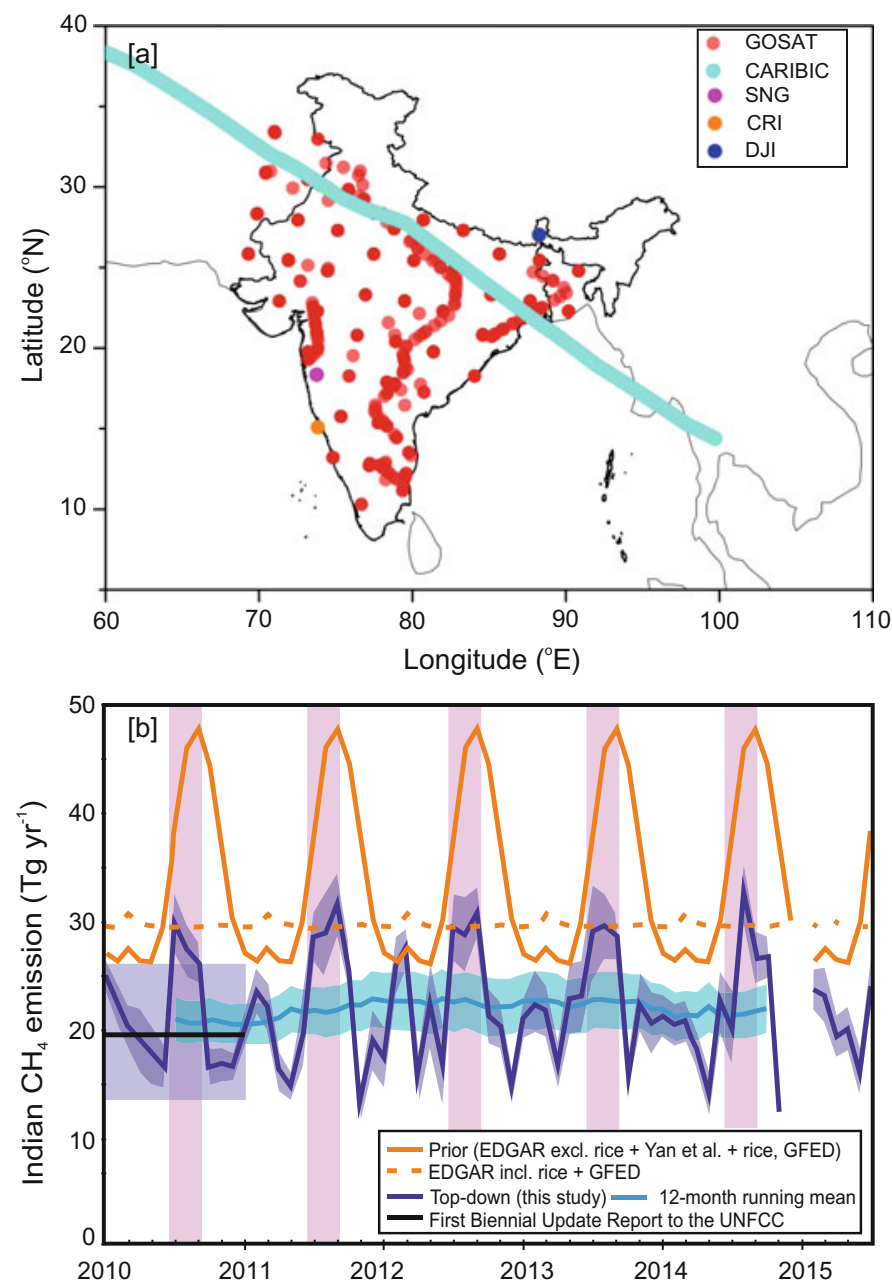

Fig. 4.4 a Map of observations used in top-down $\mathrm{CH}_{4}$ emission estimations. Typical monthly coverage from GOSAT satellite retrievals (red), CARIBIC aircraft's flight path (light blue), surface sites Darjeeling, India (dark blue), Cape Rama (CRI) Goa, India (orange), Sinhagad (SNG), Pune, India (purple). b Monthly Indian emissions estimated by EDGAR (orange line), EDGAR2010 including rice, GFED and natural emissions (dashed orange line), top-down $\mathrm{CH}_{4}$ estimations presented in Ganesan et al. (2017) (dark blue line) and 5th95th percentile range (dark blue line shading), 12-month running mean along with the 5th-95th percentile range of the running mean from this study (light blue line and shading, respectively), 2010 emissions submitted to the UNFCCC by Government of India (solid black line and uncertainties as shaded line). Ref: Ganesan et al. (2017); the figure is reproduced through an open license 
Research (EDGAR) during the same period (Fig. 4.4) and consistent with the emissions reported by India to the UNFCCC (NATCOM BUR-1 and BUR-2). The data used in Ganesan et al. (2013) are $\mathrm{XCH}_{4}$ based on the $\mathrm{CO}_{2}$ proxy method from the GOSAT satellite; flask-based measurements of dry-air $\mathrm{CH}_{4}$ mole fraction from Sinhagad $\left(73.75^{\circ}\right.$ $\left.\mathrm{E}, 18.35^{\circ} \mathrm{N}, 1600 \mathrm{~m} \mathrm{ASL}\right)$, Cape Rama, India $\left(73.83^{\circ} \mathrm{E}\right.$, $15.08^{\circ} \mathrm{N}, 60 \mathrm{~m} \mathrm{ASL}$ ), in situ measurements from Darjeeling, India $\left(88.25^{\circ} \mathrm{E}, 27.03^{\circ} \mathrm{N}, 2200 \mathrm{~m} \mathrm{ASL}\right)$; and upper-atmospheric in situ measurements from the CARIBIC aircraft (Fig. 4.4a). Further, the Lagrangian particle dispersion model, Numerical Atmospheric dispersion Modeling Environment (NAME), was used to provide a quantitative relationship between atmospheric mole fractions and emissions. However, the observation of Ganesan et al. (2017) is subjected to further verification for certain reasons. It is well known that the inverse modeling results depend strongly on the selection of chemistry transport model and treatment of atmospheric measurements. In particular, the regional transport and inverse models for long-lived gas simulation suffer from the use of boundary conditions; e.g., a recent study shows the emission estimates based on observations over Siberia are greatly affected by the trends in emissions of $\mathrm{CH}_{4}$ over Europe and Asia (Sasakawa et al. 2017). Accurate estimation of emission trends requires uninterrupted long term atmospheric observations from the region. Although Ganesan et al. (2017) used multiple streams of in situ data over India, none of the measurement locations continuously measured $\mathrm{CH}_{4}$ during the period of their analysis (20102015). The remote-sensing measurements from GOSAT do not retrieve $\mathrm{XCH}_{4}$ for the regions covered by clouds at any thickness, leading to a seasonal bias in inverse model calculation. To overcome these limitations, a well-structured GHGs long-term observational network is to be set up across India (Nalini et al. 2019).

Apart from the above activities, a few aircraft-based GHGs measurements have also been carried out over the Indian subcontinent for the vertical profiling of $\mathrm{CO}_{2}$ over Bhubaneswar, Varanasi and Jodhpur in order to study the spatiotemporal distribution of $\mathrm{CO}_{2}$ mixing ratio and inter-comparison with the satellite-derived products (Sreenivas et al. 2019). Out of these three places, Varanasi showed a strong gradient in $\mathrm{CO}_{2}$ mixing ratio (ca. $3.12 \mathrm{ppm} / \mathrm{km}$ ), while in the other two cities the gradient was much smaller $(<2 \mathrm{ppm} / \mathrm{km})$. Varanasi region being in the Indo-Gangetic Plain is characterized by strong anthropogenic loading, which has resulted in a relatively steep vertical gradient. The Cloud Aerosol Interaction and Precipitation Enhancement Experiment (CAIPEEX) Project of the Indian Institute of Tropical Meteorology also carried out similar observations during the Indian summer monsoon months of 2014, 2015 and 2018, 2019 over India and adjacent oceanic regions. The vertical profiling of methane mixing ratio revealed a strong peak at about $4.5 \mathrm{~km}$. It is believed that this kind of mid-tropospheric peak occurs due to strong convective activities (Chandra et al. 2017). Among other work, uptake of winter time carbon by the agricultural practices around Delhi has been discussed in Umezawa et al. (2016).

\subsection{Greenhouse Gas Flux Measurements in Natural Ecosystems}

GHGs fluxes are monitored over India primarily by two major measurement networks that corroborate efforts from multiple research institutes, universities and government organizations. Two important GHG components, viz., $\mathrm{CO}_{2}$ and $\mathrm{CH}_{4}$, are being monitored by the chamber-based or eddy covariance (EC) systems along with the other scalar fluxes including water vapor and energy.

Estimated $\mathrm{CO}_{2}$ flux from these measurements is subsequently used to calculate net ecosystem exchange (NEE), gross primary productivity (GPP) and total ecosystem respiration (TER) using various process-based biogeoscientific models. These parameters are the different components of the ecosystem carbon cycle. Some definitions are as follows:

NEE: The net amount of carbon exchanged (in the form of $\mathrm{CO}_{2}$ ) between the land biosphere and the atmosphere at a given location over a particular period of time; negative and positive values of NEE denote uptake and release of carbon by the land biosphere, respectively.

NEP: Net Ecosystem Productivity; opposite of NEE i.e. positive and negative values of NEP denote carbon uptake and loss by the biosphere, respectively.

NBP: Net biospheric productivity. NEP-disturbance fluxes (fire, etc.).

GPP: The total amount of carbon exchanged between the land biosphere and the atmosphere, through the process of photosynthesis.

NPP: Net primary productivity; GPP - autotrophic respiration.

TER: A part of the gross carbon uptake is lost through autotrophic, heterotrophic, microbial and soil respiration, often clubbed together as TER.

The larger value of GPP signifies greater carbon assimilation by the ecosystem; however, the net carbon uptake is defined by the NEE. In general, the carbon sequestration potential of an ecosystem depends on climatological conditions, soil moisture, texture and nutrient content, and vegetation type. Hence, for a regional or country-scale estimation of carbon budget, GHGs fluxes must be measured over different ecosystems scattered across the length and breadth of the region or the country. 


\subsubsection{Carbon Dioxide Fluxes and Net Ecosystem Exchange}

Several micrometeorological flux towers were erected for the long-term monitoring of GHGs fluxes over different ecosystems in India by the Indian Space Research Organisation (ISRO) as part of the Geosphere-Biosphere Program. These sites include a mixed deciduous teak forest in Betul over central India (Jha et al. 2013); a mangrove forest in Sundarbans on the east coast of India, flanked by the Bay of Bengal (Jha et al. 2014; Rodda et al. 2016); a mixed deciduous forest in Haldwani over north India (Watham et al. 2014; Ahongshangbam et al. 2016); and a tropical moist deciduous sal forest in Barkot over north India (Watham et al. 2017; Pillai et al. 2019).

Being deciduous in nature, the carbon exchange at the Betul forest is observed to be strongly influenced by the availability of the leaves. It is seen to act as a sink in winter with a maximum value of NEE being $-300 \mu \mathrm{gC} \mathrm{m} \mathrm{m}^{-2} \mathrm{~s}^{-1}$ in the daytime. However, the sink strength is drastically reduced to $-24 \mu \mathrm{gC} \mathrm{m}{ }^{-2} \mathrm{~s}^{-1}$ in the dry months of summer due to leaf dehiscence. Annual NEE, GPP and TER of the Betul forest were not available at the time of writing this report.

The Sundarbans mangrove acted as a net sink of $\mathrm{CO}_{2}$ with annual NEE of $-249 \pm 20 \mathrm{gC} \mathrm{m}^{-2} \mathrm{y}^{-1}$. Soil-CO emission from this ecosystem was found to vary between 18 and $28 \mu \mathrm{gC} \mathrm{m} \mathrm{m}^{-2} \mathrm{~s}^{-1}$. It remains positive throughout the year with a close dependency on the soil temperature (Chanda et al. 2014). Annual GPP and TER of this ecosystem were $1271 \mathrm{gC} \mathrm{m}^{-2} \mathrm{y}^{-1}$ and $1022 \mathrm{gC} \mathrm{m}^{-2} \mathrm{y}^{-1}$, respectively. Sink strength varied widely between $-72 \mu \mathrm{gC} \mathrm{m}^{-2} \mathrm{~s}^{-1}$ in summer and $-120 \mu \mathrm{gC} \mathrm{m} \mathrm{m}^{-2} \mathrm{~s}^{-1}$ in winter.

The 9-year-old man-made mixed forest at Haldwani acted as a net $\mathrm{CO}_{2}$ source during the leafless months of winter, quite contradictory to Betul and Sundarbans (Watham et al. 2014). Subsequently, it transformed into a sink during the growing months from April to September. The monthly mean daily total NEE of this ecosystem was $0.35 \mathrm{gC} \mathrm{m}^{-2}$ $\mathrm{d}^{-1}$, in January. It became slightly negative at $-0.38 \mathrm{gC}$ $\mathrm{m}^{-2} \mathrm{~d}^{-1}$ in February and grew farther negative continuously to $-5.74 \mathrm{gC} \mathrm{m}^{-2} \mathrm{~d}^{-1}$ in September. The annual NEE of this ecosystem was unavailable at the moment to quantify the yearlong total carbon exchange. The GPP of Barkot forest was observed to vary from $5.38 \mathrm{gC} \mathrm{m}^{-2} \mathrm{~d}^{-1}$ in December to $12.42 \mathrm{gC} \mathrm{m}^{-2} \mathrm{~d}^{-1}$ in September. This shows the gross carbon exchange to be stronger in monsoon compared to winter. The annual mean daily GPP of this ecosystem was $7.98 \mathrm{gC} \mathrm{m}^{-2} \mathrm{~d}^{-1}$. However, annual NEE is required for estimating the actual carbon sequestration by this ecosystem. Based on a three-year-long EC measurement during 2014 2016, the mixed forest at Kosi-Katarmal, Almora $\left(20.05^{\circ} \mathrm{N}\right.$, $79.05^{\circ} \mathrm{E}, 1217 \mathrm{~m} \mathrm{amsl}$ ), acted as a net sink of atmospheric $\mathrm{CO}_{2}$ with the average daily NEE being $-3.21 \mathrm{gC} \mathrm{m}^{-2} \mathrm{~d}^{-1}$ (Mukherjee et al. 2018). In another study, $\mathrm{CO}_{2}$ exchange of a wheat field was measured by an EC system at Modipuram, north India, by the ISRO (Patel et al. 2011). Maximum daytime uptake and nighttime release of $\mathrm{CO}_{2}$ by this ecosystem were observed to vary markedly during different stages of the crop growth. During the anthesis stage of the crop, maximum midday uptake and nighttime release were $-26.78 \mathrm{gC} \mathrm{m}^{-2} \mathrm{~d}^{-1}$ and $3.45 \mathrm{gC} \mathrm{m}^{-2} \mathrm{~d}^{-1}$, respectively. Due to reduced leaf area index (LAI), midday uptake drastically reduced to $-19.00 \mathrm{gC} \mathrm{m}^{-2} \mathrm{~d}^{-1}$ in the senescence stage. However, the nighttime release remained unaltered. Subsequently, in the mature stage daytime uptake further plummeted below $-11.22 \mathrm{gC} \mathrm{m}^{-2} \mathrm{~d}^{-1}$. The annual estimates of NEE, GPP and TER will be required to draw conclusion on the actual carbon sequestration of this wheat field.

The Indian Institute of Tropical Meteorology (IITM), Pune, also established a few flux towers over different ecosystems under the aegis of the MetFlux India project, initiated and funded by the Ministry of Earth Sciences (MoES), Government of India. These sites include a semievergreen moist deciduous forest in Kaziranga National Park over Northeast India (Deb Burman et al. 2017, 2019; Sarma et al. 2018), a mangrove forest in Pichavaram (Gnanamoorthy et al. 2019) on the southeast coast of India by the Bay of Bengal and an evergreen coniferous forest over the eastern Himalayan range in Darjeeling (Chatterjee et al. 2018) in Northeast India. In addition to the GHG fluxes, $\mathrm{CO}_{2}$ concentration in seawater and atmosphere is also measured in two islands, in Agatti in the Lakshadweep Islands over the Arabian Sea (Kumaresan et al. 2018) and Port Blair in the Andaman and Nicobar Islands over the Bay of Bengal as part of the MetFlux India network. The ecosystem at Kaziranga has an annual GPP of $2110 \mathrm{gC}$ $\mathrm{m}^{-2} \mathrm{y}^{-1}$ with a prominent seasonal variation primarily governed by the plant leaf phenology (Deb Burman et al. 2017). It is also reported that cloudiness during the Indian summer monsoon months drastically reduces the availability of the photosynthetically active radiation at this ecosystem which in turn affects its carbon sequestration activity negatively (Deb Burman et al. 2020b). The mangrove forest of Pichavaram in Tamil Nadu registered a NEE maximum (ca. $-11.40 \mathrm{gC} \mathrm{m}^{-2} \mathrm{~d}^{-1}$ ) during the month of January. Annual GPP and ecosystem respiration (TER) were estimated to be $1466 \mathrm{gC} \mathrm{m}^{-2} \mathrm{y}^{-1}$ and $1283 \mathrm{gC} \mathrm{m}^{-2} \mathrm{y}^{-1}$, respectively (Gnanamoorthy et al. 2020). Based on a twomonth observation at a high-altitude Himalayan evergreen forest near Darjeeling, Chatterjee et al. (2018) estimated springtime $\mathrm{CO}_{2}$ flux for the year 2015. These authors observed a maximum NEE reaching up to $-10.37 \mathrm{gC} \mathrm{m}^{-2} \mathrm{~d}^{-1}$. 
The analysis of the available annual NEE data from across the country reveals that the maximum carbon uptake (maximum negative NEE value on a diurnal scale) takes place typically in monsoon to early winter in most of the places, except in the Kaziranga forest in Northeast India. This site is characterized by maximum uptake (large negative NEE values) during the pre-monsoon time, while the minimum values typically occur in the winter. Kosi-Katarmal in north India sequesters maximum carbon during the late monsoon, though significant amount of carbon is also sequestered during the pre-monsoon time. The reason for this unusual behavior is thought to be arising partly due to the leaf phenology and partly driven by the regional climate variability. For example, the northeast region of India receives a significant amount of rainfall (driven by nor'westers) during the early summer and high sunshine (compared to the cloudy days during the monsoon time) days resulting in the increased uptake of carbon by the vegetation. The kharif (rainfed) sesame crop cultivated at Barkachha, Uttar Pradesh, in the Indo-Gangetic Plain over north India sequesters maximum $\mathrm{CO}_{2}$ during monsoon, whereas the sequestration activity is seen to be severely affected by the drought (Deb Burman et al. 2020a).

\subsubsection{Methane Fluxes}

The Sundarbans mangrove forest acted as a net source of atmospheric $\mathrm{CH}_{4}$ with average daily flux being $150.2 \pm 248.9 \mathrm{mg} \mathrm{m}^{-2} \mathrm{~d}^{-1}$ (Jha et al. 2014). Methane source was enhanced at Sundarbans during summer months due to the elevated temperature and moisture contents. Another study by Mukhophadhya et al. (2001) estimates the $\mathrm{CH}_{4}$ source from Sundarbans mangroves to lie within 4.5$8.9 \mu \mathrm{g} \mathrm{m}^{-2} \mathrm{~s}^{-1}$. The methane flux has also been measured in the Pichavaram mangrove forest. Purvaja and Ramesh (2001) used static chamber and reported methane emission in the range of $47.2-324.5 \mathrm{mg} \mathrm{m}^{-2} \mathrm{~d}^{-1}$.

Methane flux from Indian rice paddy fields is reported to vary from 2.4 to $660.0 \mathrm{mg} \mathrm{m}^{-2} \mathrm{~d}^{-1}$ (Parashar et al. 1991; Lal et al. 1993; Adhya et al. 1994). Total $\mathrm{CH}_{4}$ emission from an irrigated rice paddy field in New Delhi was reported to be $0.275-0.372 \mathrm{~g} \mathrm{~m}^{-2}$. Fertilizers such as urea, ammonium sulfate and potassium nitrate increased the $\mathrm{CH}_{4}$ emission, while dicyandiamide helped reduce it (Ghosh et al. 2003). Intermittently irrigated rice paddy fields were seen to emit less $\mathrm{CH}_{4}$ compared to the continuously flooded fields (Jain et al. 2000). A dry land rice cultivation in Varanasi, north India, was reported to be a sink of $\mathrm{CH}_{4}$ with an average growing season uptake of $8.4 \mathrm{mg} \mathrm{m}^{-2} \mathrm{~d}^{-1}$ (Singh et al. 1997). According to these authors in dry tropical ecosystems, $\mathrm{N}$ availability is remarkably low, and this may be the reason for high $\mathrm{CH}_{4}$ uptake rates in these ecosystems.
Furthermore, these dry soils are well drained and permeable, and it has been clearly demonstrated that $\mathrm{CH}_{4}$ consumption is diffusion-limited (Dörr et al. 1993). A recent study showed potential for $\mathrm{CH}_{4}$ emission by changing rice cultivation practice from conventional transplanting (CT) to system of rice intensification (SRI) in India (Oo et al. 2018). Inland water bodies such as lakes, ponds, open wells, rivers, springs and canals are known to emit $\mathrm{CO}_{2}$ and $\mathrm{CH}_{4}$ to the atmosphere. Total $\mathrm{CH}_{4}$ flux from multiple such ecosystems in India measured using flux chambers ranged from 0.16 to $834 \mathrm{mg} \mathrm{m}^{-2} \mathrm{~d}^{-1}$ (Selvam et al. 2014). Additionally, the $\mathrm{CO}_{2}$ flux from these systems was measured to lie between 0.34 and $3.15 \mathrm{gC} \mathrm{m}^{-2} \mathrm{~d}^{-1}$ (Selvam et al. 2014).

\subsubsection{Carbon Inventory of the Indian Forests}

The total carbon stored in Indian forests, including forest soil, is estimated to be in the range of $8.58-9.6 \mathrm{PgC}$ (Ravindranath et al. 2008). According to Chhabra and Dadhwal (2004), 3.8-4.3 PgC is stored as Indian forest phytomass, approximately $10 \%$ of the global forest phytomass carbon pool. Several studies assessed the influence of land use change on forest carbon (Ravindranath et al. 1997; Kaul et al. 2009). Kaul et al. (2009) estimated that net carbon flux attributable from land use change decreased from a source level of 5.65 $\mathrm{Tg} \mathrm{C} \mathrm{yr}^{-1}$ during 1982-1992 to a sink

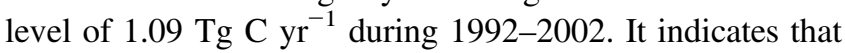
Indian forests became a sink of atmospheric carbon due to the regeneration and afforestation efforts.

\subsubsection{Agricultural Ecosystem}

Apart from the natural vegetation, agricultural ecosystems also contribute significantly to the GHGs fluxes. Specifically, the rice paddy fields are known to emit significant amounts of $\mathrm{CH}_{4}$ owing to the anaerobic conditions prevalent during the times when the fields are inundated with potentially warm water (Adhya et al. 2000). Moreover, the net emission from the agricultural ecosystems depends strongly on the agricultural practices such as applications of fertilizers, manure, pesticides, crop residue, straw and flooding of the agricultural field (Debnath et al. 1996; Singh et al. 1996; Bhatia et al. 2005). Indian Agricultural Research Institute (IARI) has several flux measurement systems across India for measuring the emissions from different agricultural fields.

\subsubsection{Other Observations}

Several satellites provide derived values of GPP, NEE and TER from space observations. Such products have also been 
compared with the ground-based estimates (Dadhwal 2012). Using SPOT VEGETATION 10-day NPP composites, Chhabra and Dadhwal (2004) estimated the total net carbon uptake by the Indian landmass to be $2.18 \mathrm{PgC}^{-1}$. Bala et al. (2013) studied the trends and variability of the terrestrial net primary productivity over India for the period of 1982-2006 using the Advanced Very-High-Resolution Radiometer (AVHRR)-derived data. These authors found an increasing trend of $3.9 \%$ per decade over India, indicating an increased rate of carbon fixation by the terrestrial ecosystems during the past two decades. NPP estimates based on Dynamic Land Ecosystem Model for the 19012000 period also show an increasing trend, from 1.2 to

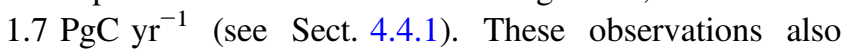
support our hypothesis of increasing $\mathrm{CO}_{2}$ amplitude due to increasing biospheric activity (discussed in Sect. 4.3.1). According to Watham et al. (2017), the MOD17 product by MODIS is a severe underestimation of the actual GPP calculated from both surface measurements and remote-sensing-driven models. Deb Burman et al. (2017) showed that MODIS LAI fails to capture the seasonality in the leaf phenology which can lead to significant error in the GPP estimate if used as input in process-based models. Ground observations over different ecosystems and satellite products are combined together for a countrywide estimate of carbon sequestration by Nayak et al. (2013). According to their study, broadleaf evergreen forests are the largest contributor to the annual carbon storage followed by broadleaf deciduous forests. Annual NEE of these ecosystems is $-1057 \mathrm{gC} \mathrm{m}^{-2} \mathrm{y}^{-1}$ and $-658 \mathrm{gC} \mathrm{m}^{-2} \mathrm{y}^{-1}$, respectively. Additionally, this upscaling study also reports an estimated growth rate of $0.005 \mathrm{PgC}^{-1}$ in the annual carbon sequestration over the Indian region.

Apart from the surface flux measurements, satellite observations are also used to estimate the GHGs fluxes. Valsala et al. (2013) studied the intra-seasonal oscillations in

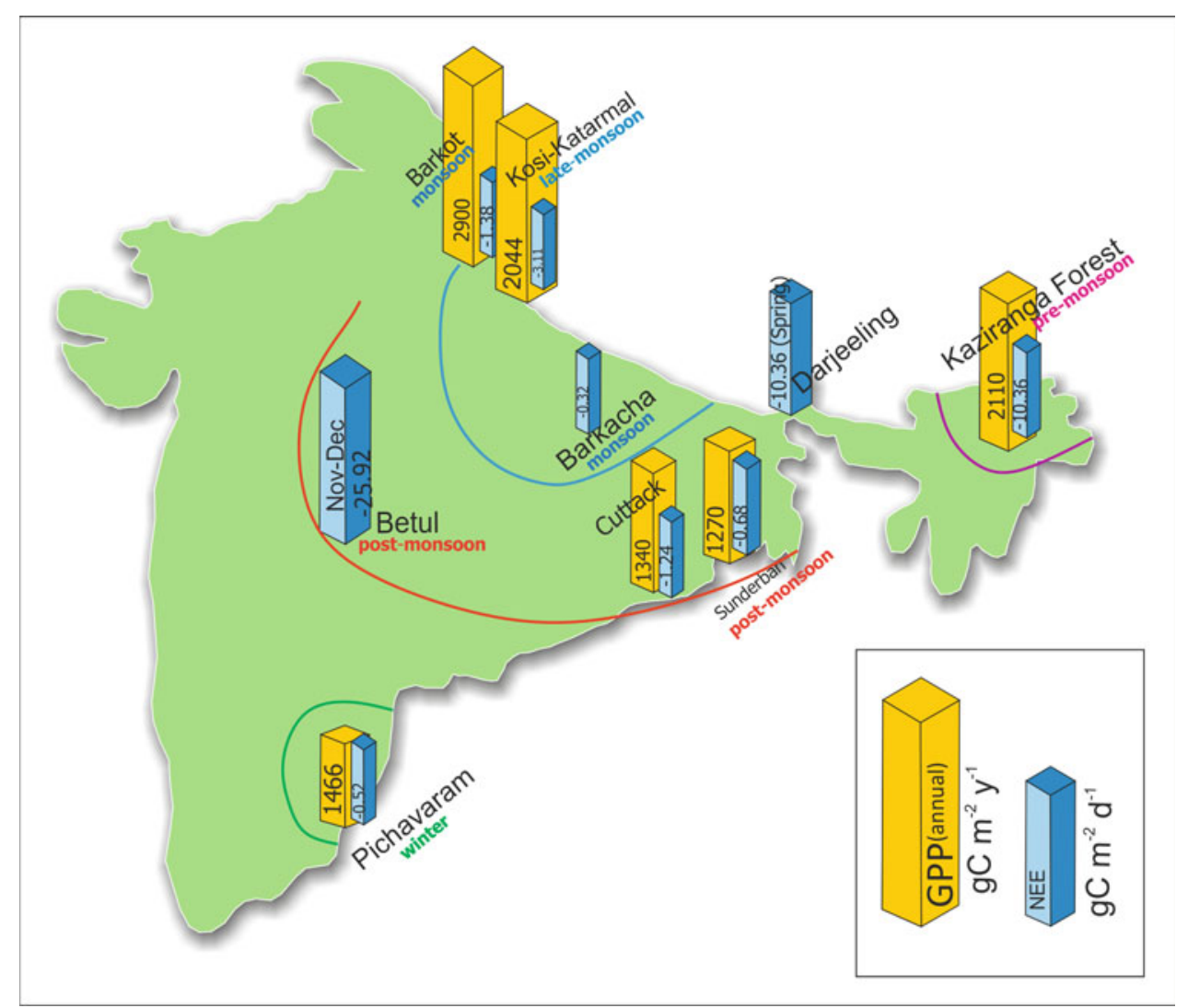

Fig. 4.5 A schematic representation of $\mathrm{CO}_{2}$ fluxes measured by the eddy covariance technique across the different ecosystems over India. The blue bars depict the maximum $\mathrm{CO}_{2}$ uptake by the vegetation on the diurnal timescale averaged for a particular season as mentioned in the figure (unit: $\mathrm{gC} \mathrm{m}^{-2} \mathrm{~d}^{-1}$ ). The yellow bar represents the GPP value for a particular ecosystem on an annual timescale (unit: $\mathrm{gC} \mathrm{m}^{-2} \mathrm{y}^{-1}$ ). Maximum carbon sequestration varies greatly with season and geography: the northeast during the pre-monsoon (represented by magenta), the Gangetic plains in monsoon (shown in blue), the north, central and east India during post-monsoon (shown in orange) and the east coast of south India during the winter (shown in green). The curved lines very approximately show the geographical variation of carbon uptake for the specific season. No data are available for the whole of the western region. The total carbon uptake by the Indian landmass is estimated to be $2.18 \mathrm{PgC} \mathrm{yr}^{-1}$ (Chhabra and Dadhwal 2004) 
terrestrial NEE during the Indian summer monsoon. These authors showed that while the terrestrial ecosystems act as a net source of $\mathrm{CO}_{2}$ during June and July, they transform into the net $\mathrm{CO}_{2}$ sink during August and September. However, due to spatial variability in GHGs distribution and dynamics, this characteristic feature may differ in specific regions. For example, the eddy covariance-based results show that the deciduous forest (Kaziranga in Assam) in the Northeast India acted as a strong sink of carbon during the pre-monsoon period (May-June; Sarma et al. 2018). On the other hand, as mentioned earlier, most of the forests in mainland India sequester significant carbon in the monsoon but maximum carbon during the post-monsoon to early winter. Hence, the study by Valsala et al. (2013) points out the limitations of satellite measurements (GHG column concentrations) in illustrating the GHGs dynamics in the Indian landmass. However during monsoon season and due to cloud cover, GHG absorption bands are obscured; hence, ground-based direct measurements of GHG are also necessary to complement the satellite measurements.

Figure 4.5 schematically shows the carbon sequestration by some Indian forests measured by means of the eddy covariance technique. The blue bar represents the maximum value of the net ecosystem exchange on the diurnal timescale for a particular month as indicated. The height is proportional to the amount of carbon uptake by the vegetation having a unit of $\mathrm{gC} \mathrm{m}^{-2} \mathrm{~d}^{-1}$. The gross primary productivity (expressed in $\mathrm{gC} \mathrm{m}^{2} \mathrm{yr}^{-1}$ ), available only for a few ecosystems, is shown as yellow bar.

\subsubsection{Nitrous Oxide Fluxes}

Another potent $\mathrm{GHG}$ is $\mathrm{N}_{2} \mathrm{O}$, which is produced in the natural biological processes occurring in soil, ocean and inland water by the microbes (Thomson et al. 2012; Davidson and Kanter 2014). Various anthropogenic activities such as agriculture, energy production, heavy industries and waste management also contribute to the rising $\mathrm{N}_{2} \mathrm{O}$ flux into the atmosphere (Wassman et al. 2004; Malla et al. 2005; Datta and Adhya 2014). Prasad et al. (2003) studied $\mathrm{N}_{2} \mathrm{O}$ emissions from India's agricultural sector between 1961 and 2000 and suggested that the total $\mathrm{N}_{2} \mathrm{O}$ emission had increased approximately 6 times over 40 years. Presently, agricultural activities alone account for more than $90 \%$ of the total anthropogenic $\mathrm{N}_{2} \mathrm{O}$ emissions in India, with $65 \%$ of the total $\mathrm{N}_{2} \mathrm{O}$ emission being attributable to the chemical fertilizers. In a study done by Ghosh et al. (2003) over an upland rice ecosystem grown during the summer monsoon months in New Delhi, $\mathrm{N}_{2} \mathrm{O}$ fluxes were found to vary within 4.32-2400 $\mu \mathrm{g} \mathrm{m}^{-2} \mathrm{~d}^{-1}$, whereas seasonal $\mathrm{N}_{2} \mathrm{O}$ loss by the ecosystem varied between 0.037 and $0.186 \mathrm{~kg} \mathrm{ha}^{-1}$. An agricultural denitrification and decomposition model was calibrated for predicting the crop yield and GHG emissions and validated for Indian conditions by Pathak et al. (2005). According to their study, continuous flooding of rice fields results in annual net emissions as follows: $21.16-60.96 \mathrm{TgC}$ in the form of $\mathrm{CO}_{2}, 1.07-1.10 \mathrm{TgC}$ in the form of $\mathrm{CH}_{4}$ and $0.04-0.05 \mathrm{TgN}$ in the form of $\mathrm{N}_{2} \mathrm{O}$, whereas intermittent flooding changes the emissions to $16.66-48.80 \mathrm{TgC}$ in the form of $\mathrm{CO}_{2}, 0.12-0.13 \mathrm{TgC}$ in the form of $\mathrm{CH}_{4}$ and $0.05-$ $0.06 \mathrm{TgN}$ in the form of $\mathrm{N}_{2} \mathrm{O}$. Noticeably, the agricultural practice of intermittent flooding of the rice paddy field had opposite effects on carbon and nitrogen emissions. An analysis using atmospheric observations and models suggests acceleration in $\mathrm{N}_{2} \mathrm{O}$ emission per unit of nitrogen fertilizer use, thus a global emission factor of $2.3 \pm 0.6 \%$, which is significantly larger than the IPCC default for combined direct and indirect emissions of $1.375 \%$ (Thompson et al. 2019).

\subsection{Model Simulation of GHGs}

\subsubsection{Biogeochemical Model Study}

Biogeochemical models are widely used to simulate the life cycles of GHGs. These models adopt a bottom-up approach to simulate the concentrations and fluxes of GHGs within and between various reservoirs such as the atmosphere, biosphere, pedosphere, geosphere and hydrosphere using mathematical representations of various biogeochemical, as well as biogeophysical, processes that affect the storage and transport of GHGs. Hence, they are able to simulate composite fluxes such as NEP and NBP that include soil dynamics as well as disturbances such as fire and land use/land cover change (Watson et al. 2000). Hence, these are more appropriate measures of the carbon source/sink status of a reservoir than GPP and NPP obtained using typical empirical methods.

Studies with biogeochemical models are very limited in the Indian context and confined to the carbon cycle in terrestrial ecosystems. Some studies have conducted simulations over India (Banger et al. 2015; Gahlot et al. 2017), while others have extracted India-specific information from global-scale biogeochemical simulations (Cervarich et al. 2016; Gahlot et al. 2017; Rao et al. 2019). Banger et al. (2015) used the Dynamic Land Ecosystem Model (DLEM) to estimate NPP patterns for the 1901-2000 period. They found that it has increased from 1.2 to $1.7{\mathrm{PgC} \mathrm{yr}^{-1}}^{\text {during }}$ this period. Using an ensemble average of nine different dynamical vegetation models, Cervarich et al. (2016) found NEP and NBP values for India to be in the $200.6 \pm 137.7{\mathrm{TgC} \mathrm{yr}^{-1}}^{-1}$ and $185.9 \pm 145.6 \mathrm{TgC} \mathrm{yr}^{-1}$ range, respectively, for the 2000-2013 period. These values are much larger than other estimates. Gahlot et al. (2017) 
Table 4.1 Comparison of net

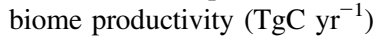
for the terrestrial ecosystems of India estimated using different approaches based on Gahlot et al. (2017)

\begin{tabular}{l|l|l|l}
\hline Decade & $1980 \mathrm{~s}$ & $1990 \mathrm{~s}$ & $2000 \mathrm{~s}$ \\
\hline Process-based models & $1.04 \pm 46.75$ & $34.65 \pm 54.16$ & $18.50 \pm 48.40$ \\
\hline Inverse models & - & $45.22 \pm 69.53$ & $42.12 \pm 67.40$ \\
\hline ISAM & 27.17 & 34.39 & 23.70 \\
\hline
\end{tabular}

conducted a comprehensive study using the Integrated Science Assessment Model (ISAM). They found that the NBP in India changed from $27.17 \mathrm{TgC} \mathrm{yr}^{-1}$ in the $1980 \mathrm{~s}$ to $34.39 \mathrm{TgC} \mathrm{yr}^{-1}$ in the $1990 \mathrm{~s}$ to $23.70 \mathrm{TgC} \mathrm{yr}^{-1}$ in the $2000 \mathrm{~s}$ indicating that the terrestrial ecosystems of India are a net carbon sink but the magnitude of the sink may be decreasing in recent years. Their estimates are comparable with results from the models involved in the TRENDY (Trends in net land carbon exchange) project (Table 4.1). Very importantly, their results show that there is a large uncertainty between different estimates of the terrestrial carbon sink.

Banger et al. (2015) and Gahlot et al. (2017) also conducted numerical experiments to quantify the impacts of various natural and anthropogenic forcings on the dynamics of the carbon cycle. They found that the net positive carbon sink is maintained mostly by the carbon fertilization effect, aided to some extent by forest conservation, management and reforestation policies in the past decade. In an idealized modeling study, Bala et al. (2011) showed that $\mathrm{CO}_{2}$-fertilization has the potential to alter the sign of terrestrial carbon uptake over India. They found that modeled carbon stocks in potential vegetation increased by $17 \mathrm{GtC}$ with unlimited fertilization for $\mathrm{CO}_{2}$ levels and climate change corresponding to the end of the 21 st century. However, the carbon stock declined by $5.5 \mathrm{GtC}$ when fertilization is limited at 1975 levels of $\mathrm{CO}_{2}$ concentration. Thus, the benefits from $\mathrm{CO}_{2}$ fertilization could be partially offset by land use/land cover change and climate change (Bala et al. 2011). Further, the model simulations of Bala et al. (2011) also implied that the maximum potential terrestrial sequestration over India, under equilibrium conditions and best-case scenario of unlimited $\mathrm{CO}_{2}$ fertilization, is only $18 \%$ of the twenty-first-century SRES A2 scenario emissions from India. The limited uptake potential suggests that reduction of $\mathrm{CO}_{2}$ emissions and afforestation programs should be top priorities for India.

The broader trends, variability and drivers of the carbon cycle dynamics over India were comprehensively addressed by Rao et al. (2019) using the multi-model dataset TRENDY for the period 1900-2010. Their analysis showed that the TRENDY multi-model mean NPP shows a positive trend of $2.03 \%$ per decade over India during this period which is consistent with a global greening in the last two decades (Chen et al. 2019) and other studies such as Bala et al. (2013) which showed an NPP increase of about $4 \%$ per decade during the satellite era. Rao et al. (2019) also analyzed the trends in water-use efficiency (WUE) of ecosystem in India and found that WUE has increased by 25\% during the period 1900-2010. Further, it was found that the inter-annual variation in NPP and NEP over India is strongly driven by precipitation, but remote drivers such as El Nino-Southern Oscillation (ENSO) and Indian Ocean Dipole (IOD) may not have a strong influence. The multi-model-based estimate of the cumulative NEE is only $0.613 \pm 0.1 \mathrm{PgC}$ during 1901-2010, indicating that the Indian terrestrial ecosystem was neither a strong source nor a significant sink during this period. Among other studies, Chakraborty et al. (1994) used proxy-based atmospheric and surface ocean radiocarbon records to estimate the $\mathrm{CO}_{2}$ exchange rate in the coastal region of Gujarat. Using a box model approach, these authors have estimated $\mathrm{CO}_{2}$ exchange rate in the tune of $12 \mathrm{~mol} \mathrm{~m}^{-2} \mathrm{yr}^{-1}$.

\subsubsection{Greenhouse gases Emission and Projections}

In this chapter, we present projections of future changes based on the SSPs (Shared Socioeconomic Pathways) - a suite of future forcing scenarios being used for the latest generation of climate model (CMIP6) experiments. The SSPs describe five possible future emissions trajectories based on different narratives of socio-economic developments in the future. It may be noted that the future forcing scenarios used by the previous generation of climate models (CMIP5) were based on the Representative Concentration Pathways (RCPs; see Chap. 1).

The future projection of GHGs emissions may be understood in light of the shared socioeconomic pathways (SSPs) by climate change researcher community, which takes an account of qualitative and quantitative trends in population growth, economic development, urbanization and education leading to future development of nations. The narratives of these are discussed in detail in O'Neill et al. (2017). These SSPs are developed using integrated assessment models. These are considered to be new scenarios designed under 5 pathways, namely SSP1, SSP2, SSP3, SSP4 and SSP5 out of which SSP1, SSP3, SSP4 and SSP5 are based on different levels of challenges to climate adaptation and mitigation while SSP2 is a median pathway considering a moderate challenge to both (O'Neill et al. 2014, 2017). Briefly, these SSPs are named and understood as: 
SSP1: Sustainability, in which the world gradually shifts toward a more sustainable path where the development happens considering the environmental boundaries.

SSP2: Middle of the road pathway, where social, economic and technological developments follow a historical trend, leading to uneven progress among the countries and slowly attaining sustainable goals.

SSP3: Regional rivalry, where there is increased competitiveness among the countries to attain development and policies are mostly oriented toward empowering national securities and local issues.

SSP4: Inequalities, where uneven investments and policies enhance the inequalities among and within the countries' increase. Energy demand increases so as the consumption of carbon as well as low-carbon energy sources.

SSP5: Fossil-fueled development; investment in technological progress and human capital is considered a way to achieve sustainable development. To cater the increasing energy demand for achieving economic development, this world still primarily relies on the fossil fuel resources.

Further details about these SSPs can be found in Calvin et al. (2016), Fricko et al. (2016), Fujimori et al. (2016), Hasegawa et al. (2018), Kriegler et al. (2016), van Vuuren et al. (2016). Emission projections are made using these SSPs in MAGICC6 (Model for the Assessment of Greenhouse Gas-Induced Climate Change) climate model and are available as 9 CMIP6 emission scenarios, 4 of which are in line with the radiative forcings of 2.6, 4.5, 6.0 and $8.5 \mathrm{~W} \mathrm{~m}^{-2}$ of RCPs of CMIP5 projections as SSP1-2.6, SSP2-4.5, SSP4-6.0 and SSP5-8.5. The 5 additional intermediate scenarios cover vivid possibilities of forcing targets during emergence of these scenarios in future as SSP1-1.9, SSP3-7.0, SSP3-low near-term climate forcing (LowNTCF), SSP4-3.4 and SSP5-3.4 Overshoot (OS). Out of these, SSP3-7.0 and SSP5-8.5 are baseline scenarios, considering no additional policies are brought into the action to mitigate GHGs emission other than the existing policies. Considering the base year as 2015, all these scenarios were then harmonized for smooth transition between the historical data and these projections and downscaled at country level (Gidden et al. 2018).

Future projections for India's GHG emissions, primarily $\mathrm{CO}_{2}$ and $\mathrm{CH}_{4}$, under different SSPs up to the year 2100 are shown in Fig. 4.6 where $\mathrm{CO}_{2}$ emissions span over a large range of 2-16 Gt- $\mathrm{CO}_{2} \mathrm{yr}^{-1}$ under different scenarios and $\mathrm{CH}_{4}$ emissions span over $10-90 \mathrm{Mt} \mathrm{yr}^{-1}$. The data were sourced from Riahi et al. (2017). In India, emission projections under four SSPs and a total of 8 scenarios are available, SSP1-1.9, SSP1-2.6, SSP3-7.0, SSP3-LowNTCF, SSP4-3.4, SSP4-6.0, SSP5-3.4 OS and SSP5-8.5. SSP1-1.9 is considered a greener world where energy consumption is based on more green and renewable energy sources, restricting the radiative forcing to $1.9 \mathrm{~W} \mathrm{~m}^{-2}$ which is in accordance with the recent Paris Agreement. Trajectories represent the immediately decreasing $\mathrm{CO}_{2}$ emissions. In SSP1-2.6 which also implies a greener world, but the radiative forcing reaches a level of $2.6 \mathrm{~W} \mathrm{~m}^{-2}, \mathrm{CO}_{2}$ emission tends to decrease, but slightly less than that of SSP1-1.9 in the future due to investment in green energy. India's $\mathrm{CO}_{2}$ emissions are projected to peak by the year 2030 and gradually decrease thereafter. $\mathrm{CH}_{4}$ emissions are projected to decrease gradually by the year 2100 to its lowest value hovering around one-third of present emission. India's (intended) nationally determined contribution under the Paris Agreement commits to reduce the emission intensity of its GDP by $33-35 \%$ by 2030 from 2005 level and to achieve about $40 \%$ cumulative electric power installed capacity from non-fossil fuel-based energy sources by 2030. These SSP projections are in line with the green and sustainable world with least GHGs emissions from India as well in such scenario.

In SSP3-70 and SSP3-LowNTCF, there is a consistent increase in $\mathrm{CO}_{2}$ emissions till the end of the century at almost the same rate. For $\mathrm{CH}_{4}$, there is an increase in SSP3-70 scenario, but in the SSP3-LowNTCF scenario, where the policies are to reduce the forcing due to short-lived species, a sharp decrease after 2020 and then a slight increase are projected till the end of the century. $\mathrm{CO}_{2}$ increase is attributed to the increased power consumption to meet the growing energy demand mostly by relying on fossil fuels and carbon-based energy sources along with the change in land use, whereas $\mathrm{CH}_{4}$ emissions are dominated by agriculture (cultivation and livestock) as of now, also contributed by energy sector and waste management. Under the SSP3-70 scenario while $\mathrm{CO}_{2}$ emission tends to increase about four times the present emission, increase in $\mathrm{CH}_{4}$ emission is projected to rapidly increase after 2020 and shall be tripled by the end of the century; in fact, $\mathrm{CH}_{4}$ emissions are seen to reach higher values in this scenario among all the cases.

SSP4 projection is in the world of unequal development. In SSP4-6.0, where radiative forcing is restricted to $6 \mathrm{~W} \mathrm{~m}^{-2}$, India's emission of both $\mathrm{CO}_{2}$ and $\mathrm{CH}_{4}$ is projected to peak around the middle of the century, after which it stabilizes and shows a decreasing tendency around the year 2060 probably due to the inclusion of investments in better technologies and sustainable energy sources in the future. While $\mathrm{CO}_{2}$ emissions tend to stabilize toward the end of this century around today's emission rate, $\mathrm{CH}_{4}$ emissions are on the higher side, even after an anticipated decline in emission in the latter half of the century. In SSP4-3.4, $\mathrm{CO}_{2}$ 
Fig. 4.6 Emission trajectories of (a) $\mathrm{CO}_{2}$, and (b) $\mathrm{CH}_{4}$ for India under different CMIP6 emission scenarios
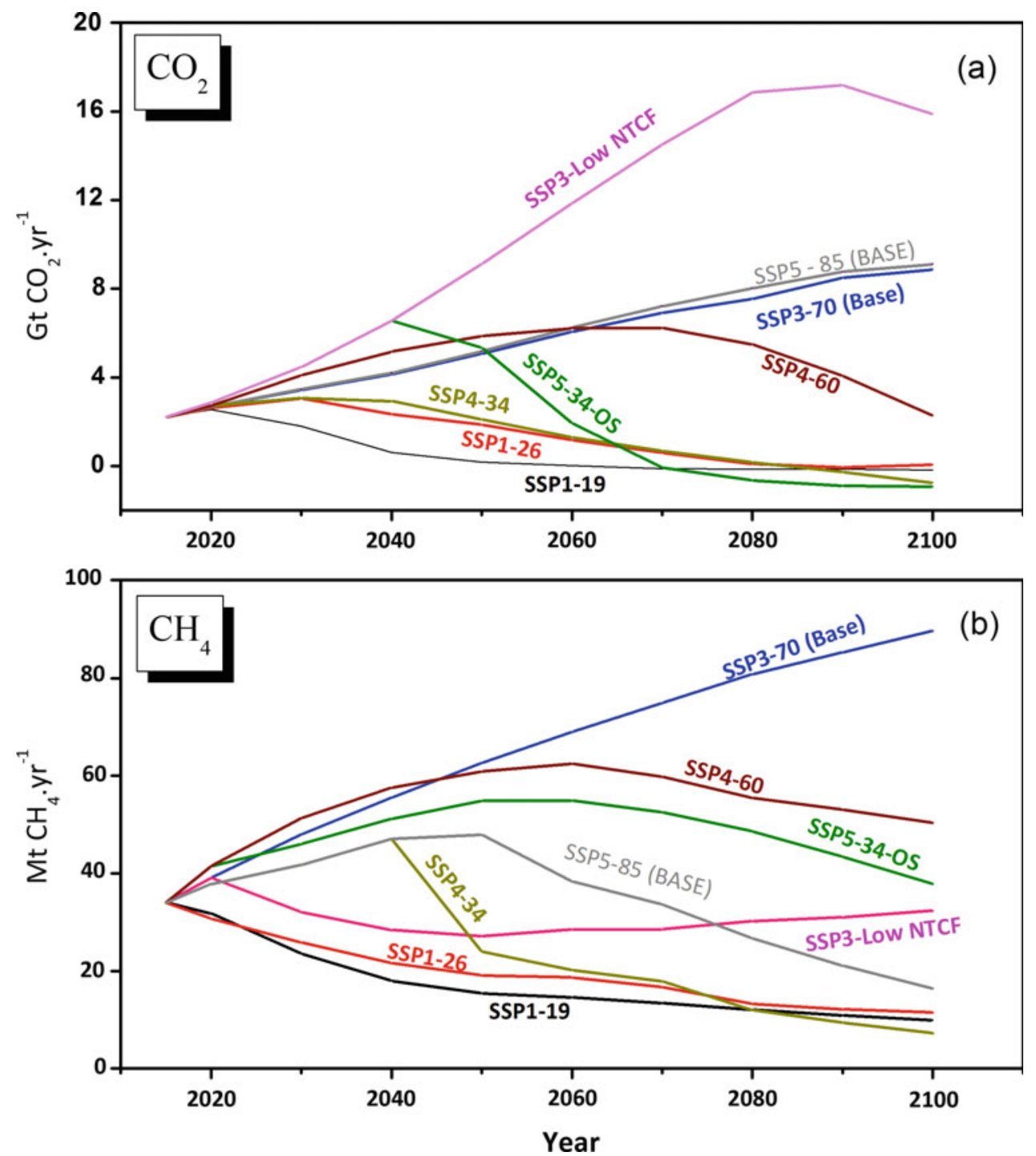

emission trajectories are toward decreasing trend in the near future and $\mathrm{CH}_{4}$ emission trajectories following slightly lesser than the SSP4-6.0 trend.

In $\mathrm{SSP} 5, \mathrm{CO}_{2}$ emissions are projected to follow an increasing trend for the next few decades and stabilize itself around the year 2080. It then slightly decreases by 2100 , but yields the highest emission of $\mathrm{CO}_{2}$ as a result of socioeconomic development powered by fossil fuel. Projected emissions hover at the highest rate of $16,000 \mathrm{Mt} \mathrm{CO}_{2} \mathrm{yr}^{-1}$. $\mathrm{CH}_{4}$ emission is projected to increase till 2040 and stabilize itself in a decade, and by 2050 it starts decreasing and ends up to the values near the emission values as projected in SSP1. This decrease in $\mathrm{CH}_{4}$ emission may be attributed to better agriculture practices, livestock management and land usage as a result of investment in technologies.

\subsection{Knowledge Gaps}

The seasonal-scale atmospheric $\mathrm{CO}_{2}$ concentrations typically show high amplitude in the high latitude region and low in the tropical areas. Despite being a tropical country, the Indian $\mathrm{CO}_{2}$ variability shows unusually large seasonal cycle and an increasing trend in the $\mathrm{CO}_{2}$ values. So, whether the natural and/or the anthropogenic emission of carbon is controlling the $\mathrm{CO}_{2}$ amplitude needs to be properly understood.

A lack of long-term record and sparse observational data limits our ability to comprehensively assess the biogeochemical cycle of carbon over India. The eddy covariance-based data of NEE are available only for a few 
forested and agricultural environments. It is also believed that trees emit significant amount of methane, especially in forested environment; no study to ascertain and quantify the plant-derived methane emission exists in India. This poses a serious constraint in making an accurate estimation of the net ecosystem productivity and in turn the carbon sequestration potential of the Indian forests. A large amount of vapor is generated through the process of transpiration, but their role in modulating the monsoon processes remains largely unknown. Apart from insufficient observational data, there are no significant studies for Indian region to quantify this effect by climate modeling. Development and use of coupled climate-carbon models could help identify the sources and sinks of both carbon dioxide and water vapor fluxes. Inverse models have been shown to reliably estimate the sources and sinks of the GHGs, but insufficient observed data pose a serious challenge to achieve the task in the Indian context. Likewise, the role of the oceanic GHG emission on the terrestrial carbon cycle also remains poorly constrained.

One of the important parameters is the carbon isotopic values of certain GHGs, such as $\mathrm{CO}_{2}$ and $\mathrm{CH}_{4}$, which are known to provide valuable information about the sources, but their use in the Indian context is almost nonexistent. With the advent of new technology (i.e., laser-based cavity ring-down spectroscopy), real-time in situ monitoring of GHGs concentrations and their isotopes are possible (Mahesh et al. 2015; Chakraborty et al. 2020). Use of outputs from such instruments would greatly enhance our capability to characterize the GHGs source and sink patterns on a higher temporal and regional scale.

With increasing population and rapid industrialization, energy demand for the country is increasing at a rapid pace resulting in more GHGs emissions. But there is no network of observations available to monitor these emissions and to have a better understanding of sources and sink pattern over the country. In this context, there is an urgent need to develop a countrywide surface GHGs concentration observational network and their fluxes at all the major ecosystems and urban hotspots.

Other issues, such as the sensitivity of the photosynthetic sink and the respiration-driven sources of carbon to increased warming, relation between the $\mathrm{CO}_{2}$ and other green house gas fluxes with the intra-seasonal variation of rainfall across the ecosystems, need to be investigated.

The scope of research needs to be expanded using process-based modeling of carbon cycle to quantify the role of different natural and anthropogenic factors. These models do not rely on the remote-sensing data and hence can be used to study the pre-satellite era as well as develop future scenarios. Development of a coupled climate and GHG cycle model constrained and validated by an extensive observational network would strengthen the effort in unraveling the regional sources and sinks of the GHGs and develop realistic projections of the future.

\subsection{Summary}

The observational records of $\mathrm{CO}_{2}$ and $\mathrm{CH}_{4}$ concentration are available from a West Indian location (Sinhagad) for the last several years. This is one of the very few flask-based measurements that is currently underway in India on a long-term perspective.

The observation shows that the amplitude of $\mathrm{CO}_{2}$ mixing ratio has been increasing progressively for the past several years. The mechanism responsible for producing such variability is not fully understood, but is likely to be linked to the changes in vegetation and forest cover.

Reports available on Indian forest cover expansion (contraction) are not coherent. Systematic efforts are required to address these issues. The measurement of surface $\mathrm{CO}_{2}$ concentration over a wide geographical area must be carried out on a long-term basis. Analysis of such kind of records has been proven to be an effective means to assess the biospheric activity.

Use of satellite-derived vegetation indices (proxy of terrestrial biosphere) indicates an increasing trend (ca. $4 \%$ per decade) during the last two decades in India. Also, the NPP estimates based on Dynamic Land Ecosystem Model for the 1901-2000 period show an increasing trend, from 1.2 to 1.7 PgC.yr ${ }^{-1}$.

The available surface GHGs concentration observations, albeit from a limited area, indicate the role of marine processes, especially during the summer monsoon season, in determining the seasonal pattern of $\mathrm{CO}_{2}$ and $\mathrm{CH}_{4}$ fluxes. However, quantification of this process needs to be done for a better understanding of the GHGs dynamics.

The atmosphere-biosphere exchange of $\mathrm{CO}_{2}$ tends to be active during summer monsoon and maximum during post-monsoon seasons of India. However, the Kaziranga forest in Northeast India appears to sequester maximum carbon during the pre-monsoon season.

The net ecosystem exchange (NEE) of carbon derived from satellite retrievals gives only a gross estimate over a wide region. Considerable differences exist with the eddy covariance-based in situ observations at several places.

A robust network of eddy covariance-based observations consisting of a large number of micrometeorological tower setup over the diverse ecosystems across the country can lead to a better understanding of the biogeochemical cycles.

$\mathrm{CO}_{2}$ and $\mathrm{CH}_{4}$ projections for the Indian environment have been made under different CMIP6 emission scenarios. Without rapid mitigation policies, atmospheric $\mathrm{CO}_{2}$ and $\mathrm{CH}_{4}$ loading will continue to increase for the next several decades. 
However, with more sustainable approaches using green technologies these rising trends can be controlled.

Carbon cycle study in India using the biogeochemical models is still in its infancy. Process-based modeling of GHGs cycle coupled with general circulation models should be developed to estimate the sources and sinks, and identify the transport of the GHGs contributed by different natural and anthropogenic factors. This could be carried out in association with the radiocarbon analysis of atmospheric $\mathrm{CO}_{2}$ in order to partition the emission due to fossil fuel burning and agricultural practices and/or natural processes.

\section{References}

Adhya T, Rath A, Gupta P et al (1994) Methane emission from flooded rice fields under irrigated conditions. Biol Fertil Soils 18:245-248

Adhya TK, Mishra SR, Rath AK et al (2000) Methane efflux from rice-based cropping systems under humid tropical conditions of eastern India. Agr Ecosyst Environ 79:85-90

Ahongshangbam J, Patel NR, Kushwaha SPS, Watham T, Dadhwal VK (2016) Estimating gross primary production of a forest plantation area using eddy covariance data and satellite imagery. J Indian Soc Remote Sens 44:895-904

Bala G, Gopalakrishnan R, Jayaraman M, Nemani R, Ravindranath NH (2011) $\mathrm{CO}_{2}$-fertilization and potential future terrestrial carbon uptake in India. Mitig Adapt Strat Gl 16:143-160

Bala G, Joshi J, Chaturvedi RK, Gangamani HV, Hashimoto H, Nemani R (2013) Trends and variability of AVHRR-derived NPP in India. Remote Sens 5:810-829. https://doi.org/10.3390/rs5020810

Banger K, Tian H, Tao B, Ren W, Pan S, Dangal S, Yang J (2015) Terrestrial net primary productivity in India during 1901-2010: contributions from multiple environmental changes. Clim Change 132(4):575-588. https://doi.org/10.1007/s10584-015-1448-5

Barlow JM, Palmer PI, Bruhwiler LM, Tans P (2015) Analysis of $\mathrm{CO}_{2}$ mole fraction data: first evidence of large-scale changes in $\mathrm{CO}_{2}$ uptake at high northern latitudes. Atmos Chem Phys 15:1373913758. https://doi.org/10.5194/acp-15-13739-2015

Berhanu TA, Szidat S, Brunner D, Satar E, Schanda R, Nyfeler P, Battaglia M, Steinbacher M, Hammer S, Leuenberger M (2017) Estimation of the fossil fuel component in atmospheric $\mathrm{CO}_{2}$ based on radiocarbon measurements at the Beromünster tall tower, Switzerland. Atmos Chem Phys 17:10753-10766

Bhatia A, Pathak H, Jain N, Singh PK, Singh AK (2005) Global warming potential of manure amended soils under rice-wheat system in the Indo-Gangetic plains. Atmos Environ 39:6976-6984

Bhattacharya SK, Borole DV, Francey RJ, Allison CE, Steele LP, Krummel P, Langenfelds R, Masarie KA, Tiwari YK, Patra PK (2009) Trace gases and $\mathrm{CO}_{2}$ isotope records from Cabo de Rama, India. Curr Sci 97:1336-1344

Bose T, Chakraborty S, Borgaonkar HP, Sengupta S, Ramesh R (2014) Estimation of past atmospheric carbon dioxide levels using tree-ring cellulose d13C. Curr Sci 107(6):971-982

Calvin K, Bond-Lambert B, Clarke L, Edmonds J, Eom J, Hartin C, Kim S, Kyle P, Link R, Moss R, McJeon H, Patel P, Smith S, Waldhoff S, Wise M (2016) SSP4: a world of inequality. Glob Environ Change. https://doi.org/10.1016/j.gloenvcha.2016.06.010

Cervarich $\mathrm{M}$ et al (2016) The terrestrial carbon budget of South and Southeast Asia. Environ Res Lett 11(10). https://doi.org/10.1088/ $1748-9326 / 11 / 10 / 105006$
Chakraborty S, Ramesh R, Krishnaswami S (1994) Air-sea exchange of $\mathrm{CO}_{2}$ in the Gulf of Kutch, northern Arabian Sea based on bomb-carbon in corals and tree rings. Proc Indian Acad Sci (Earth Planet Sci) 103:329-340

Chakraborty S, Dutta K, Bhattacharyya A, Nigam M, Schuur EAG, Shah $\mathrm{S}$ (2008) Atmospheric ${ }^{14} \mathrm{C}$ variability recorded in tree rings from Peninsular India: implications for fossil fuel $\mathrm{CO}_{2}$ emission and atmospheric transport. Radiocarbon 50(3):321-330

Chakraborty S, Metya A, Datye A, Deb Burman PK, Sarma D, Gogoi N, Bora A (2020) Eddy covariance and CRDS based techniques of GHGs measurements provide additional constraint in partitioning the net ecosystem exchange. EGU General Assembly 2020 Abstract volume; https://doi.org/10.5194/egusphere-egu2020901

Chanda A, Akhand A, Manna S, Dutta S, Hazra S et al (2013) Characterizing spatial and seasonal variability of carbon dioxide and water vapour fluxes above a tropical mixed mangrove forest canopy, India. J Earth Sys Sci 122:503-513

Chanda A, Akhand A, Manna S et al (2014) Measuring daytime $\mathrm{CO}_{2}$ fluxes from the inter-tidal mangrove soils of Indian Sundarbans. Environ Earth Sci 72:417-427

Chandra N, Hayashida S, Saeki T, Patra PK (2017) What controls the seasonal cycle of columnar methane observed by GOSAT over different regions in India? Atmos Chem Phys 17:12633-12643. https://doi.org/10.5194/acp-17-12633-2017

Chandra N, Venkataramani S, Lal S, Patra PK, Ramonete M, Lin X, Sharma SK (2019) Observational evidence of high methane emissions over a city in western India. Atmos Environ 202:41-52

Chatterjee A, Roy A, Chakraborty S, Sarkar C, Singh S, Karipot AK, Ghosh SK, Mitra A, Raha S (2018) Biosphere atmosphere exchange of $\mathrm{CO}_{2}, \mathrm{H}_{2} \mathrm{O}$ vapour and energy during spring over a high altitude Himalayan forest in eastern India. Aerosol Air Qual Res. https://doi. org/10.4209/aaqr.2017.12.0605

Chhabra A, Dadhwal VK (2004) Estimating terrestrial net primary productivity over India using satellite data. Curr Sci 86:269-271

Chen C, Park T, Wang X, Piao S, Xu B, Chaturvedi RK, Fuchs R, Brovkin V, Ciais P, Fensholt R, Tømmervik H, Bala G, Zhu Z, Nemani RR, Myneni RB (2019) China and India lead in greening of the world through land-use management. Nat Sustain 2:122-129

Ciais P, et al (2014) Carbon and other biogeochemical cycles. Climate change 2013: the physical science basis. Contribution of Working Group I to the Fifth Assessment Report of the Intergovernmental Panel on Climate Change. Cambridge University Press, pp 465-570

Dadhwal VK (2012) Assessment of Indian carbon cycle components using earth observation systems and ground inventory. ISPRS Int Arch Photogram Remote Sens Spat Inf Sci XXXIX-B8:249-254

Datta A, Adhya TK (2014) Effects of organic nitrification inhibitors on methane and nitrous oxide emission from tropical rice paddy. Atmos Environ 92:533-545

Davidson EA, Kanter D (2014) Inventories and scenarios of nitrous oxide emissions. Environ Res Lett 9:105012. https://doi.org/10. 1088/1748-9326/9/10/105012

Deb Burman PK, Sarma D, Williams M, Karipot A, Chakraborty S (2017) Estimating gross primary productivity of a tropical forest ecosystem over north-east India using LAI and meteorological variables. J Earth Syst Sci 126:99. https://doi.org/10.1007/s12040017-0874-3

Deb Burman PK, Sarma D, Morrison R, Karipot A, Chakraborty S (2019) Seasonal variation of evapotranspiration and its effect on the surface energy budget closure at a tropical forest over north-east India. J Earth Syst Sci 128:127. https://doi.org/10.1007/s12040$019-1158-x$

Deb Burman PK, Shurpali NJ, Chowdhuri S, Karipot A, Chakraborty S, Lind SE, Martikainen PJ, Arola A, Tiwari YK, Murugavel P, 
Gurnule D, Todekar K, Prabha TV (2020a) Eddy covariance measurements of $\mathrm{CO}_{2}$ exchange from agro-ecosystems located in subtropical (India) and boreal (Finland) climatic conditions. J Earth Syst Sci 129:43. https://doi.org/10.1007/s12040-019-1305-4

Deb Burman PK, Sarma D, Chakraborty S, Karipot A, Jain AK (2020b) The effect of Indian summer monsoon on the seasonal variation of carbon sequestration by a forest ecosystem over north-east India. SN Appl Sci 2:154. https://doi.org/10.1007/s42452-019-1934-x

Debnath G, Jain MC, Kumar S, Sarkar K, Sinha SK (1996) Methane emissions from rice fields amended with biogas slurry and farm yard manure. Clim Change 33:97-109

Dlugokencky EJ, Nisbet EG, Fisher R, Lowry D (2011) Global atmospheric methane: budget, changes and dangers. Philos Trans $\mathrm{R}$ Soc A Math Phys Eng Sci. https://doi.org/10.1098/rsta.2010.0341

Dörr H, Katruff L, Levin I (1993) Soil texture parameterization of the methane uptake in aerated soils. Chemosphere 26:698-713. https:// doi.org/10.1016/0045-6535(93)90454-D

Etheridge DM, et al (1998) Atmospheric methane between 1000 AD and present: evidence of anthropogenic emissions and climatic variability. J Geophys Res Atmos 103.D13(1998):15979-15993. https://doi.org/10.1029/98JD00923

Fricko O, Havlik P, Rogelj J, Riahi K, Klimont Z, Gusti M, Johnson N, Kolp P, Strubegger M, Valin H, Amann M, Ermolieva T, Forsell N, Herrero M, Heyes C, Kindermann G, Krey V, McCollum DL, Obersteiner M, Pachauri S, Rao S, Schmid E, Schoepp W (2016) SSP2: a middle-of-the-road scenario for the 21st century. Glob Environ Change. https://doi.org/10.1016/j.gloenvcha.2016.06.004

Fujimori S, Hasegawa T, Masui T, Takahashi K, Herran DS, Dai H, Hijioka Y, Kainuma M (2016) AIM implementation of shared socioeconomic pathways. Glob Environ Change. https://doi.org/10. 1016/j.gloenvcha.2016.06.009

Gahlot S, Shu S, Jain AK, Baidya Roy S (2017) Estimating trends and variation of net biome productivity in India for 1980-2012 using a land surface model. Geophys Res Lett 44. https://doi.org/10.1002/ $2017 \mathrm{~g} 1075777$

Ganesan AL, Chatterjee A, Prinn RG, Harth CM, Salameh PK, Manning AJ, Hall BD, Mühle J, Meredith LK, Weiss RF, O'Doherty S, Young D (2013) The variability of methane, nitrous oxide and sulfur hexafluoride in Northeast India. Atmos Chem Phys 13:10633-10644. https://doi.org/10.5194/acp-13-10633-2013

Ganesan AL, Rigby M, Lunt MF, Parker RJ, Boesch H, Goulding N, Umezawa T, Zahn A, Chatterjee A, Prinn RG, Tiwari YK, van der Schoot M, Krummel PB (2017) Atmospheric observations show accurate reporting and little growth in India's methane emissions. Nat Commun 8. Article 836. https://doi.org/10.1038/s41467-01700994-7

Garg A, Kankal B, Shukla PR (2011) Methane emissions in India: sub-regional and sectoral trends. Atmos Environ 45(28):4922-4929. https://doi.org/10.1016/j.atmosenv.2011.06.004

Ghosh S, Majumdar D, Jain MC (2003) Methane and nitrous oxide emissions from an irrigated rice of north India. Chemosphere 51:181-195

Gidden MJ, Riahi K, Smith SJ, Fujimori S, Luderer G, Kriegler E, van Vuuren DP et al (2018) Global emissions pathways under different socioeconomic scenarios for use in CMIP6: a dataset of harmonized emissions trajectories through the end of the century. Geosci Model Dev Discuss 2018:1-42. https://doi.org/10.5194/gmd2018266

Gnanamoorthy P, Selvam V, Ramasubramanian R, Chakraborty S, Deb Burman PK, Karipot A (2019) Diurnal and seasonal patterns of soil $\mathrm{CO}_{2}$ efflux from south east coastal Indian mangrove. Environ Monit Assess 191:258. https://doi.org/10.1007/s10661-019-7407-2

Gnanamoorthy P, Selvam V, Deb Burman PK, Chakraborty S, Nagarajan R, Karipot A, Ramasubramanian R, Grace J (2020)
Seasonal variations of carbon dioxide, water vapor and energy fluxes in Indian tropical mangrove forest of Pichavaram using eddy covariance technique. Estuar Coast Shelf Sci (in press)

Hasegawa T, Havlik P, Hilaire J, Hoesly R, Horing J, Popp A, Stehfest E, Takahashi K (2018) Global emissions pathways under different socioeconomic scenarios for use in CMIP6: a dataset of harmonized emissions trajectories through the end of the century. Geosci Model Dev Discuss (in review). https://doi.org/10.5194/ gmd-2018-266

IPCC (2007) Forster P, Ramaswamy V, Artaxo P, Berntsen T, Betts R, Fahey DW, Haywood J, Lean J, Lowe DC, Myhre G, Nganga J, Prinn R, Raga G, Schulz M, Van DR. Changes in atmospheric constituents and in radiative forcing. In: Solomon S, Qin D, Manning M, Chen Z, Marquis M, Averyt KB, Tignor M, Miller HL (eds) Climate change 2007: the physical science basis. Contribution of working group I to the fourth assessment report of the Intergovernmental Panel on Climate Change. Cambridge University Press, Cambridge, New York

IPCC, Climate Change (2013) The physical science basis. In: Stocker TF, Qin D, Plattner G-K, Tignor M, Allen SK, Boschung J, Nauels A, Xia Y, Bex V, Midgley PM (eds) Contribution of working group I to the fifth assessment report of the Intergovernmental Panel on Climate Change. Cambridge University Press, Cambridge, New York, 1535 pp

Jain MC, Kumar S, Wassmann R et al (2000) Methane emissions from irrigated rice fields in northern India (New Delhi). Nutr Cycl Agroecosyst 58:75-83

Jain SK, Kumar V, Saharia M (2013) Analysis of rainfall and temperature trends in northeast India. Int J Climatol 33:968-978

Jha CS, Thumaty KC, Rodda SR, Sonakia A, Dadhwal VK (2013) Analysis of carbon dioxide, water vapour and energy fluxes over an Indian teak mixed deciduous forest for winter and summer months using eddy covariance technique. J Earth Syst Sci 122:1259-1268

Jha CS, Rodda SR, Thumaty KC, Raha AK, Dadhwal VK (2014) Eddy covariance based methane flux in Sundarbans mangroves, India. J Earth Syst Sci 123:1089-1096

Kaul M, Dadhwal VK, Mohren GMJ (2009) Land use change and net C flux in Indian forests. For Ecol Manage 258:100-108

Keppler F, Hamilton JTG, Brass M, Röckmann T (2006) Methane emissions from terrestrial plants under aerobic conditions. Nature 439:187-191. https://doi.org/10.1038/nature04420

Kriegler E, Bauer N, Popp A, Humpenöder F, Leimbach M, Strefler J, Baumstark L, Bodirsky B, Hilaire J, Klein D, Mouratiadou I, Weindl I, Bertram C, Dietrich J-P, Luderer G, Pehl M, Pietzcker R, Piontek F, Lotze-Campen H, Biewald A, Bonsch M, Giannousakis A, Kreidenweis U, Müller C, Rolinski S, Schwanitz J, Stefanovic M (2016) Fossil-fueled development (SSP5): an energy and resource intensive scenario for the 21st century. Glob Environ Change. https://doi.org/10.1016/j.gloenvcha.2016.05.015

Kumaresan S, Shekhar S, Chakraborty S, Sundaramanickama A, Kuly N (2018) Environmental variables and nutrients in selected islands of Lakshadweep Sea; addressing coral bleaching. Reg Stud Mar Sci 22:38-48

Lal S, Venkataramani S, Subbaraya B (1993) Methane flux measurements from paddy fields in the tropical Indian region. Atmos Environ 27:1-3

Lin X, Indira NK, Ramonet M, Delmotte M, Ciais P, Bhatt BC, Reddy MV, Angchuk D, Balakrishnan S, Jorphail S, Dorjai T, Mahey TT, Patnaik S, Begum M, Brenninkmeijer C, Durairaj S, Kirubagaran R, Schmidt M, Swathi PS, Vinithkumar NV, Yver Kwok C, Gaur VK (2015) Long-lived atmospheric trace gases measurements in flask samples from three stations in India. Atmos Chem Phys 15:9819-9849. https://doi.org/10.5194/acp-15-98192015 
Liu DN, Guo XD, Xiao BW (2019) What causes growth of global greenhouse gas emissions? Evidence from 40 countries. Sci Total Environ 661:750-766. https://doi.org/10.1016/j.scitotenv.2019.01.197

Mahesh P, Sharma N, Dadhwal VK, Rao PVN, Apparao BV, Ghosh AK, Mallikarjun K, Ali MM (2014) Impact of land-sea breeze and rainfall on $\mathrm{CO}_{2}$ variations at a coastal station. J Earth Sci Clim Change 5:6

Mahesh P, Sreenivas G, Rao PVN, Dadhwal VK, Sai Krishna SVS, Mallikarjun K (2015) High-precision surface-level $\mathrm{CO}_{2}$ and $\mathrm{CH}_{4}$ using off-axis integrated cavity output spectroscopy (OA-ICOS) over Shadnagar, India. Int J Remote Sens 36(22):5754-5765. https://doi.org/10.1080/01431161.2015.1104744

Mahesh P, Sreenivas G, Rao PVN, Dadhwal VK (2016) Atmospheric $\mathrm{CO}_{2}$ retrieval from ground based FTIR spectrometer over Shadnagar, India. Atmos Meas Tech Discuss. https://doi.org/10.5194/amt2016-177

Mahesh P, Gaddamidi S, Gharai B, Mullapudi Venkata Rama SS, Kumar Sundaran R, Wang W (2019) Retrieval of $\mathrm{CO}_{2}, \mathrm{CH}_{4}, \mathrm{CO}$ and $\mathrm{N}_{2} \mathrm{O}$ using ground-based FTIR data and validation against satellite observations over the Shadnagar, India. Atmos Meas Tech Discuss. https://doi.org/10.5194/amt-2019-7

Malla G, Bhatia A, Pathak H, Prasad S, Jain N, Singh J (2005) Mitigating nitrous oxide and methane emissions from soil in rice-wheat system of the Indo-Gangetic plain with nitrification and urease inhibitors. Chemosphere 58:141-147

Meiyappan P et al (2017) Dynamics and determinants of land change in India: integrating satellite data with village socioeconomics. Reg Environ Change 17:753-766. https://doi.org/10.1007/s10113-0161068-2

Metya A, Datye A, Chakraborty S, Tiwari Y (2020) Diurnal and seasonal variability of $\mathrm{CO}_{2}$ and $\mathrm{CH}_{4}$ concentrations in a semi-urban environment of western India. Theor Appl Climatol (under review)

MoEFCC (2015) India: first biennial update report to the United Nations framework convention on climate change. Ministry of Environment, Forest and Climate Change, Government of India

MoEFCC (2018) India: second biennial update report to the United Nations framework convention on climate change. Ministry of Environment, Forest and Climate Change, Government of India

Mukherjee S, Sekar KC, Lohani P, Kumar K, Patra P, Ishijima K (2018) Investigation of scale interaction between rainfall and ecosystem carbon exchange of Western Himalayan Pine dominated vegetation. Biogeosci Discuss. https://doi.org/10.5194/bg-2018-299

Mukhophadhya SK, Biswas H, Das KL, Jana TK (2001) Diurnal variation of carbon dioxide and methane exchange above Sundarbans mangrove forest, in NW coast of India. Indian J Mar Sci 30:70-74

Nalini K, Sijikumar S, Valsala V, Tiwari YK, Ramachandran R (2019) Designing surface $\mathrm{CO}_{2}$ monitoring network to constrain the Indian land fluxes. Atmos Environ 218:117003

Nayak RK, Patel NR, Dadhwal VK (2013) Inter-annual variability and climate control of terrestrial net primary productivity over India. Int J Climatol 33:132-142

O'Neill BC, Kriegler E, Riahi K, Ebi KL, Hallegatte S, Carter TR, Mathur R, Van Vuuren DP (2014) A new scenario framework for climate change research: the concept of shared socioeconomic pathways. Clim Change 122:387-400

O’Neill BC, Kriegler E, Ebi KL, Kemp-Benedict E, Riahi K, Rothman DS, Van Ruijven BJ, Van Vuuren DP, Birkmann J, Kok K, Levy M, Solecki W (2017) The roads ahead: narratives for shared socioeconomic pathways describing world futures in the 21st century. Glob Environ Change 42:169-180

Oo AZ, Sudo S, Inubushi K, Mano M, Yamamoto A, Ono K, Osawa T, Hayashida S, Patra PK, Terao Y, Elayakumar P, Vanitha K, Umamageswari C, Jothimani P, Ravi V (2018) Methane and nitrous oxide emissions from conventional and modified rice cultivation systems in South India. Agric Ecosyst Environ 252:148-158

Parashar D, Rai J, Gupta P, Singh N (1991) Parameters affecting methane emission from paddy fields. Indian J Radio Space Phys 20:12-17

Parker RJ et al (2015) Assessing 5 years of GOSAT Proxy $\mathrm{XCH}_{4}$ data and associated uncertainties. Atmos Meas Tech 8:4785-4801

Patel NR, Dadhwal VK, Saha SK (2011) Measurement and scaling of carbon dioxide $\left(\mathrm{CO}_{2}\right)$ exchanges in wheat using flux-tower and remote sensing. J Ind Soc Remote Sens 39:383-391

Pathak H, Li C, Wassmann R (2005) Greenhouse gas emissions from Indian rice fields: calibration and upscaling using the DNDC model. Biogeosciences 2:113-123

Patra PK et al (2009) Growth rate, seasonal, synoptic, diurnal variations and budget of methane in the lower atmosphere. J Meteorol Soc Jpn 87:635-663. https://doi.org/10.2151/jmsj.87.635

Patra PK et al (2013) The carbon budget of South Asia. Biogeosciences 10:513-527. https://doi.org/10.5194/bg-10-513-2013

Patra PK, Saeki T, Dlugokencky EJ, Ishijima K, Umezawa T, Ito A, Aoki S, Morimoto S, Kort EA, Crotwell A, Ravikumar K, Nakazawa T (2016) Regional methane emission estimation based on observed atmospheric concentrations (2002-2012). J Meteorol Soc Jpn 94:91-113

Pillai ND, Nandy S, Patel NR, Srinet R, Watham T (2019) Integration of eddy covariance and process-based model for the intra-annual variability of carbon fluxes in an Indian tropical forest. Biodivers Conserv. https://doi.org/10.1007/s10531-019-01770-3

Prasad VK, Lata M, Badarinath KVS (2003) Trace gas emissions from biomass burning from northeast region in India-estimates from satellite remote sensing data and GIS. Environmentalist 23:229-236

Purvaja R, Ramesh R (2001) Natural and anthropogenic methane emission from coastal wetlands of south India. Environ Manage 27:547-557

Rao AS, Bala G, Ravindranath NH, Nemani R (2019) Multi-model assessment of trends, variability and drivers of terrestrial carbon uptake in India. J Earth Syst Sci 128:1-19. https://doi.org/10.1007/ s12040-019-1120-y

Ravindranath NH, Somashekhar BS, Gadgil M (1997) Carbon flow in Indian forests. Clim Change 35:297-320

Ravindranath NH, Chaturvedi RK, Murthy IK (2008) Forest conservation, afforestation and reforestation in India: implications for forest carbon stocks. Curr Sci 95:216-222

Riahi K, Van Vuuren DP, Kriegler E, Edmonds J, O'Neill B, Fujimori SNB, Calvin K, Dellink R, Fricko O, Lutz W, Popp A, Crespo Cuaresma J, Leimbach M, Kram T, Rao S, Emmerling J, Hasegawa T, Havlik P, Humpenöder F, Aleluia Da Silva L, Smith SJ, Stehfest E, Bosetti V, Eom J, Gernaat D, Masui T, Rogelj J, Strefler J, Drouet L, Krey V, Luderer G, Harmsen M, Takahashi K, Wise M, Baumstark L, Doelman J, Kainuma M, Klimont Z, Marangoni G, Moss R, Lotze-Campen H, Obersteiner M, Tabeau A, Tavoni M (2017) The shared socio-economic pathways and their energy, land use and greenhouse gas emissions implications: an overview. Glob Environ Change 42:148-152

Rigby M, Prinn RG, Fraser PJ, Simmonds PG, Langenfelds RL, Huang J, Cunnold DM, Steele LP, Krummel PB, Weiss RF, O'Doherty S, Salameh PK, Wang HJ, Harth CM, Muhle J, Porter LW (2008) Renewed growth of atmospheric methane. Geophys Res Lett 35:L22805. https://doi.org/10.1029/ 2008GL036037

Rodda S, Thumaty K, Jha C, Dadhwal V (2016) Seasonal variations of carbon dioxide, water vapor and energy fluxes in tropical Indian mangroves. Forests 7:35

Sarma D, Baruah KK, Baruah R, Gogoi N, Chakraborty S, Karipot AK (2018) Carbon dioxide, water vapour and energy fluxes over a semi 
evergreen forest in Assam, Northeast India using eddy covariance technique. J Earth Syst Sci. https://doi.org/10.1007/s12040-0180993-5

Sasakawa M, Machida T, Ishijima K, Arshinov M, Patra PK, Ito A, Aoki S, Petrov V (2017) Temporal characteristics of $\mathrm{CH}_{4}$ vertical profiles observed in the West Siberian Lowland over Surgut from 1993 to 2015 and Novosibirsk from 1997 to 2015. J Geophys Res (Atmos). https://doi.org/10.1002/2017JD026836

Schuck TJ et al (2010) Greenhouse gas relationships in the Indian summer monsoon plume measured by the CARIBIC passenger aircraft. Atmos Chem Phys 10:3965-3984

Selvam B, Natchimuthu S, Arunachalam L et al (2014) Methane and carbon dioxide emissions from inland waters in India-implications for large scale greenhouse gas balances. Glob Change Biol 20:3397-3407

Sharma N, Nayak RK, Dadhwal VK, Kant Y, Ali MM (2013) Temporal variations of atmospheric $\mathrm{CO}_{2}$ in Dehradun, India during 2009. Air Soil Water Res 6:37-45

Sharma $\mathrm{N}$ et al (2014) Atmospheric $\mathrm{CO}_{2}$ variations in two contrasting environmental sites over India. Air Soil Water Res 7:61-68. https:// doi.org/10.4137/aswr.s13987

Singh JS, Singh S, Raghubanshi AS, Singh S, Kashyap AK (1996) Methane flux from rice/wheat agroecosystem as affected by crop phenology, fertilization and water level. Plant Soil 183:323-327

Singh JS, Raghubanshi AS, Reddy VS, Singh S, Kashyap AK (1997) Methane flux from irrigated paddy and dryland rice fields, and from seasonally dry tropical forest and savanna soils of India. Soil Biol Biochem 30:135-139

Sreenivas G, Mahesh P, Subin J, Kanchana AL, Rao PVN, Dadhwal VK (2016) Influence of meteorology and interrelationship with greenhouse gases $\left(\mathrm{CO}_{2}\right.$ and $\left.\mathrm{CH}_{4}\right)$ at a suburban site of India. Atmos Chem Phys 16:3953-3967

Sreenivas G, Mahesh P, Biswadip G, Suresh S, Rao PVN, Krishna Chaitanya M, Srinivasulu P (2019) Spatio-temporal distribution of $\mathrm{CO}_{2}$ mixing ratio over Bhubaneswar, Varanasi and Jodhpur of India -airborne campaign, 2016. Atmos Environ. https://doi.org/10. 1016/j.atmosenv.2019.01.010

Stocker TF et al (2013) IPCC, 2013: climate change 2013: the physical science basis. Contribution of working group I to the fifth assessment report of the Intergovernmental Panel on Climate Change

Thomson AJ, Giannopoulos G, Pretty J, Baggs EM, Richardson DJ (2012) Biological sources and sinks of nitrous oxide and strategies to mitigate emissions. Philos Trans R Soc B Biol Sci 367. https:// doi.org/10.1098/rstb.2011.0415
Thompson RL, Lassaletta L, Patra PK et al (2019) Acceleration of global $\mathrm{N}_{2} \mathrm{O}$ emissions seen from two decades of atmospheric inversion. Nat Clim Change 9:993-998. https://doi.org/10.1038/ s41558-019-0613-7

Tiwari YK, Patra PK, Chevallier F, Francey RJ, Krummel PB, Allison CE, Revadekar JV, Chakraborty S, Langenfelds RL, Bhattacharya SK, Borole DV, Kumar KR, Steele LP (2011), $\mathrm{CO}_{2}$ observations at Cape Rama, India for the period of 1993-2002: implications for constraining Indian emissions. Curr Sci 101 (12):1562-1568. ISSN: 0011-3891

Tiwari YK, Vellore RK, Kumar KR, van der Schoot M, Cho C-H (2014) Influence of monsoons on atmospheric $\mathrm{CO}_{2}$ spatial variability and ground-based monitoring over India. Sci Total Environ 490:570-578. https://doi.org/10.1016/j.scitotenv.2014.05. 045. ISSN: 0048-9697

Umezawa T, Niwa Y, Sawa Y, Machida T, Matsueda H (2016) Winter crop $\mathrm{CO}_{2}$ uptake inferred from CONTRAIL measurements over Delhi, India. Geophys Res Lett 43:11859-11866. https://doi.org/10. 1002/2016gl070939

Valsala V, Tiwari YK, Pillai P, Roxy M, Maksyutov S, Murtugudde R (2013) Intraseasonal variability of terrestrial biospheric $\mathrm{CO}_{2}$ fluxes over India during summer monsoons. J Geophys Res Biogeosci 118:752-769

van Vuuren DP, Stehfest E, Gernaat D, Doelman J, van Berg M, Harmsen M, de Boer H-S, Bouwman LF, Daioglou V, Edelenbosch O, Girod B, Kram T, Lassaletta L, Lucas P, van Meijl H, Müller C, van Ruijven B, Tabeau A (2016) Energy, land-use and greenhouse gas emissions trajectories under a green growth paradigm. Glob Environ Change. https://doi.org/10.1016/j. gloenvcha.2016.05.008

Wassman R, Neue H, Ladha J, Aulakh M (2004) Mitigating greenhouse gas emissions from rice-wheat cropping systems in Asia. Environ Dev Sustain 6:65-90

Watham T, Kushwaha SP, Patel NR, Dadhwal VK (2014) Monitoring of carbon dioxide and water vapour exchange over a young mixed forest plantation using eddy covariance technique. Curr Sci 107:858-866

Watham T, Patel NR, Kushwaha SPS, Dadhwal VK, Kumar AS (2017) Evaluation of remote-sensing-based models of gross primary productivity over Indian sal forest using flux tower and MODIS satellite data. Int J Remote Sens 38:5069-5090

Watson RT, Noble I, Bolin B, Ravindranath NH, Verardo DJ, Dokken DJ (2000) Land use, land-use change, and forestry. A special report. Intergovernmental Panel on Climate Change, Washington. http://www.grida.no/climate/ipcc/land_use/024.htm
Open Access This chapter is licensed under the terms of the Creative Commons Attribution 4.0 International License (http:// creativecommons.org/licenses/by/4.0/), which permits use, sharing, adaptation, distribution and reproduction in any medium or format, as long as you give appropriate credit to the original author(s) and the source, provide a link to the Creative Commons license and indicate if changes were made.
The images or other third party material in this chapter are included in the chapter's Creative Commons license, unless indicated otherwise in a credit line to the material. If material is not included in the chapter's Creative Commons license and your intended use is not permitted by statutory regulation or exceeds the permitted use, you will need to obtain permission directly from the copyright holder. 